\title{
How Vulnerable Are Arab Countries to Global Food Price Shocks?
}

\author{
May 2014 \\ Elena I. Ianchovichina,* Josef L. Loening,** \& Christina A. Wood* \\ *Chief Economist Office, Middle East and North Africa, the World Bank, \\ Washington DC, USA, **African Development Bank, Dar es Salaam, Tanzania
}

\begin{abstract}
We estimate pass-through effects of international food price movements into domestic food prices for eighteen countries in the Middle East and North Africa, using threshold regressions. International price movements transmit to various degrees into domestic prices. Transmission is mostly asymmetric, pushing domestic price levels up, as increases in international food prices are typically passed through, but declines are rarely transmitted. This situation is indicative of policy and market distortions, notably the presence of food subsidies in the context of fiscal constraints. Hence, both international prices and their volatility matter for domestic inflation, yet domestic factors also play a role.
\end{abstract}

Keywords: Inflation; food price pass-through; food subsidies; fiscal policy; Arab world; Middle East and North Africa; threshold regression.

JEL: C22; E31; E37

\section{Introduction}

The Middle East and North Africa ${ }^{1}$ (MENA) stands out among other developing regions for its extensive use of food price subsidies and controls (Ortiz et al., 2011). ${ }^{2}$ At the same time, food price inflation has been a concern in the region. Despite the use of price stabilizing policies, some researchers have cited rapidly rising food prices as a contributing factor to the popular discontent leading to the Arab Spring events (for example, Breisinger et al., 2011; Lagi et al., 2011; Zurayk, 2011). Indeed, as international food prices rose substantially during the second half of the 2000s and perceivably became more volatile during the $2000 \mathrm{~s}^{3}$ (Figure 1), domestic food prices also rose across many MENA countries (see online Appendix Table A1). ${ }^{4}$ The regions' dependence on imported food is substantial, and likely to grow in the future. This is because of high population growth and climate change, which can raise the 
frequency of draughts and water scarcity. The region is already the largest wheat importer in the world and imports about half of its overall staple crop consumption requirements. High malnutrition rates in the developing MENA countries suggest that a large number of households continue to be vulnerable to food price shocks.

In this article we assess the extent to which international food price movements have been transmitted into domestic food prices in MENA. Our results indicate that both international food price levels and volatility ${ }^{5}$ matter, as transmission is highly asymmetric. Increases in international food prices are typically passed into domestic prices, but declines are rarely transmitted. This situation is indicative of policy and market distortions, notably the presence of food subsidies in the context of fiscal constraints. Our results also suggest that global price movements transmit partially and to various degrees across economies in the region. It takes about a year for partial transmission to completely unfold - on average a $1 \%$ increase in world food prices can increase domestic food prices by some $0.2-0.4 \%$. The pass-through effects are notably higher in Egypt, Iraq, Djibouti, and the United Arab Emirates (UAE), suggesting greater degree of integration between domestic and global food markets in these economies. By contrast, Algeria and Tunisia appear less affected. ${ }^{6}$ External factors are not the only source of domestic food price inflation in the region. Domestic factors contributed more than $50 \%$ of the cumulative increase in domestic food prices in about half of the economies in the region. Domestic factors were particularly important in Iran, the Gulf Cooperation Council (GCC) economies, Syria, Algeria, Tunisia, and Lebanon.

\section{Figure 1. World Food Price Levels and Inflation, 1984:01-2011:12}

(Level, Index June 2005=100)

(\%, year-on-year change)
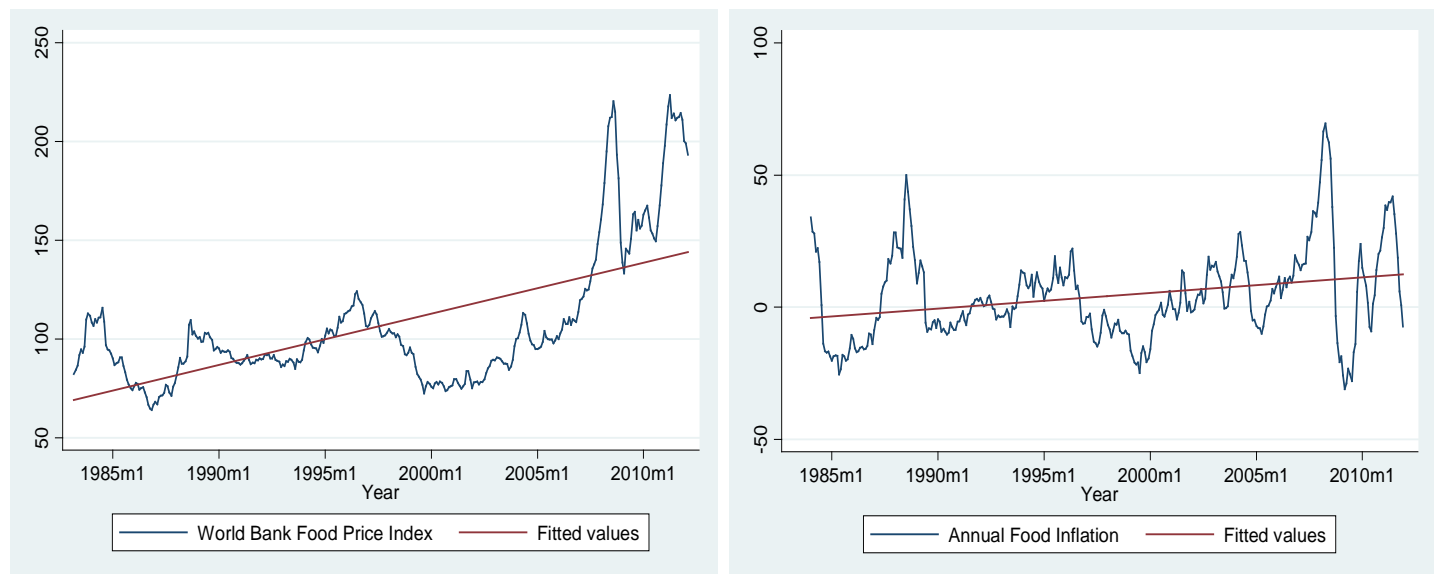

Source: World Bank. 
Substantial increases in international food prices in the 2000s and fast-growing domestic food demand have increased the fiscal cost of food subsidies, and provided impetus for initiating reforms of food subsidy programs in the region. ${ }^{7}$ Some governments have been more successful than others in cutting subsidies and improving targeting. Measures such as self-targeting, increasing prices by stealth, subsidy rationing, and replacing subsidies with cash transfers, have all been employed with various degree of success. However, most economies still offer food subsidies, as reforms were often partial or reversed under public pressure in the context of the Arab Spring events. Economies where food subsidies increased or price controls were imposed during the first half of 2011 include Bahrain, Kuwait, Oman, the UAE, Algeria, Yemen, Jordan, Egypt, Tunisia, and Morocco (World Bank, 2011a; World Bank, 2011b).

High international food prices can build up inflationary pressures and complicate macroeconomic management. Due to high food shares in the consumption basket of many MENA economies ${ }^{8}$ and second-round effects, high domestic food inflation can have long-lasting effects on overall (headline) inflation, particularly in countries with less firmly anchored inflationary expectations (Walsh, 2011). Food inflation can also be transmitted to core inflation through higher inflationary expectations and workers' demands for wage increases. In the MENA region, food inflation appears to exhibit strong short-run effects on non-food inflation (IMF, 2011).

The literature provides little empirical insight into the extent to which international food price shocks influence domestic prices in individual MENA economies. Exceptions are Albers and Peeters (2011), who present food price transmission effects for a few countries in the Mediterranean region, and Crowley (2010), who finds that international commodity prices exhibit a strong and significant effect on domestic consumer prices for a cross-section panel of countries in the region. Limited access to data has been a key reason for the absence of empirical work on most MENA countries. This article, therefore, fills a void in the literature as it puts together a database of monthly domestic food price indexes from 2000 to 2011 and uses these data to estimate the pass-through effects of international food price movements into domestic food prices for eighteen MENA economies.

Section 2 reviews the empirical literature on the pass-through effects of international food price shocks to domestic markets and presents a conceptual framework on the role of food subsidies in the transmission process. Section 3 
documents the data and presents statistics of MENA's potential exposure to food price shocks, including dependency ratios by food commodity. Section 4 details the econometric approach, while section 5 presents the pass-through estimates. Section 6 offers concluding remarks.

\section{The Pass-through Literature and the Role of Subsidies}

The empirical literature on the transmission of international food price shocks to domestic markets is abundant, but information on MENA countries is largely absent. Studies on the topic rely on different econometric approaches, use data for different periods and levels of commodity aggregation, and often reach different conclusions. Since disaggregate data are limited, most studies tend to rely on aggregate food indexes, although in these instances full price transmission ${ }^{9}$ cannot be expected due to differences in the world and domestic food baskets. Anderson and Tyers (1992) use error-correction models to compute short and long-run transmission elasticities for changes in border prices relative to domestic producer prices for 30 countries and 7 agricultural commodities for the period 1961-1983. Quiroz and Soto (1995) estimate an aggregate food price pass-through elasticity for 78 countries between 1966 and 1991. For about one third of the developing countries in their sample, they find no transmission even in the long-run, while in the rest of the developing countries their estimates suggest that it could take years to transmit a world price shock to domestic prices. By contrast, Mundlak and Larson (1992) present high transmission elasticities for world prices and exchange rates for 58 countries (1968-78), but as argued by Quiroz and Soto (1995), this might be due to a spurious regression problem, which they corrected in their own study. A number of other papers (Baffes and Gardner, 2003; Hazell et al., 1990; Sharma, 2003) report mixed evidence of the effects of world food price fluctuations on domestic producer prices in the developing countries. Recent analyses that rely on Vector Auto-Regressions (VAR) include IMF (2011) and Ferrucci et al. (2010). The latter find that international commodity prices are the main determinant of producer and consumer food price inflation in the Euro area. However, in a comprehensive meta-analysis, Greb et al. (2012) compare their own econometric estimates on price transmission with those in the literature and find generally weak evidence of price transmission from co-integration analysis for the developing countries, possibly due to shifts in the policy regime, asymmetry of price transmission effects, or other factors including data and methodological issues. They also find that 
the time period and type of commodity greatly matters for cereal price transmission. Overall, most studies find incomplete transmission of world food price shocks into domestic markets around the world. ${ }^{10}$

Empirical studies rarely explain the choice of methodology or the reasons for the less than full transmission. However, some papers shed light on this issue. Fackler and Goodwin (2001) and Barret (2001) acknowledge that empirical tests for food markets often reject the law of one price. Failure of empirical tests to support the law of one price for food markets are believed to stem from problems with measurement, especially of transport and transaction costs, shifts in the domestic policy regime, and market characteristics. All of these factors imply that long-run, co-integration or error-correction parameters may yield insignificant results.

Building on these findings, we develop a conceptual model that motivates our empirical approach. According to the Takayama and Judge (1971) spatial equilibrium theory, and following Adam (2011), the relationship between the export parity price, the import parity price, and domestic food prices is:

$$
\left(1-c_{x}\right)\left(1-t_{x}\right) E p^{W} \leq p \leq\left(1+c_{m}\right)\left(1+t_{m}\right) E p^{W}
$$

where $c$ and $t$ denote transport costs and tariffs on exports $x$ and imports $m$; $E$ is the nominal exchange rate, $p^{W}$ is the international price of food, and $p$ is the domestic price of food. Since the economies of the Middle East and North Africa are net food importers, domestic prices will follow closely the import parity price, modified here to reflect the presence of subsidies s, widely used in the MENA region:

$$
p=\left(1+c_{m}\right)\left(1+t_{m}\right) E p^{w}-\mathrm{s}
$$

If we rearrange and represent relationship (2) in percentage changes, we obtain the following dependency between domestic and world prices:

$$
\Delta p=\frac{(p+s)}{p}\left[\left(\frac{c_{m}}{1+c_{m}}\right) \Delta c_{m}+\left(\frac{t_{m}}{1+t_{m}}\right) \Delta t_{m}+\Delta E+\Delta p^{W}-\left(\frac{s}{p+s}\right) \Delta s\right] .
$$

Assuming transport costs, border protection, and exchange rates ${ }^{11}$ remain fixed at their initial levels, the link between the domestic and world prices is given by the following expression:

$$
\Delta p=\left(\frac{p+s}{p}\right) \Delta p^{W}-\left(\frac{s}{p}\right) \Delta s .
$$


Expression (4) shows that shocks to world prices are transmitted to domestic prices, unless there is a corresponding change in subsidies:

$$
\Delta s=\left(\frac{p+s}{s}\right) \Delta p^{W} .
$$

As shown by (5), subsidies can be used to insulate completely domestic prices from world food price changes, but when international food prices are increasing at a rapid pace, subsidies will also have to increase rapidly to keep domestic prices stable. This is not always possible, especially in economies with limited fiscal space and high import food dependency. ${ }^{12}$ Empirical information, available for a few countries in developing MENA, supports this view. During the period 2007-2009 national food prices increased substantially, ${ }^{13}$ but food subsidies mostly declined or stagnated, except in Egypt, where they increased. ${ }^{14}$

Figure 2 shows the case of a country that levies specific subsidy $s$ on food imports. The world food price $p^{W}$ is expressed in local currency units ${ }^{15}$ and other factors, which create a wedge between domestic prices $p$ and $p^{W}$, such as transport costs and border protection, are assumed to be negligible for the sake of simplicity. Food subsidy $s$ lowers the domestic price $p$ below the world price $p^{W}$ and raises imports from $M_{0}$, the quantity that would be consumed in the case of parity between domestic and international prices, to $M$. We also assume that the objective of the government is to keep domestic food prices stable via price subsidies on imported food. In the MENA region, commitment to price stability is signaled by the prevalence of price controls on certain types of food products. Price controls can be viewed as flexible subsidies that can perfectly accommodate price fluctuations. According to Ortiz et al. (2011), some countries - including Algeria, Morocco, Jordan, and Djibouti - use price controls on certain food products. Other Arab economies use both price controls and price subsidies.

\section{Figure 2. Food Subsidies, Food Price Shocks, and Fiscal Constraints}

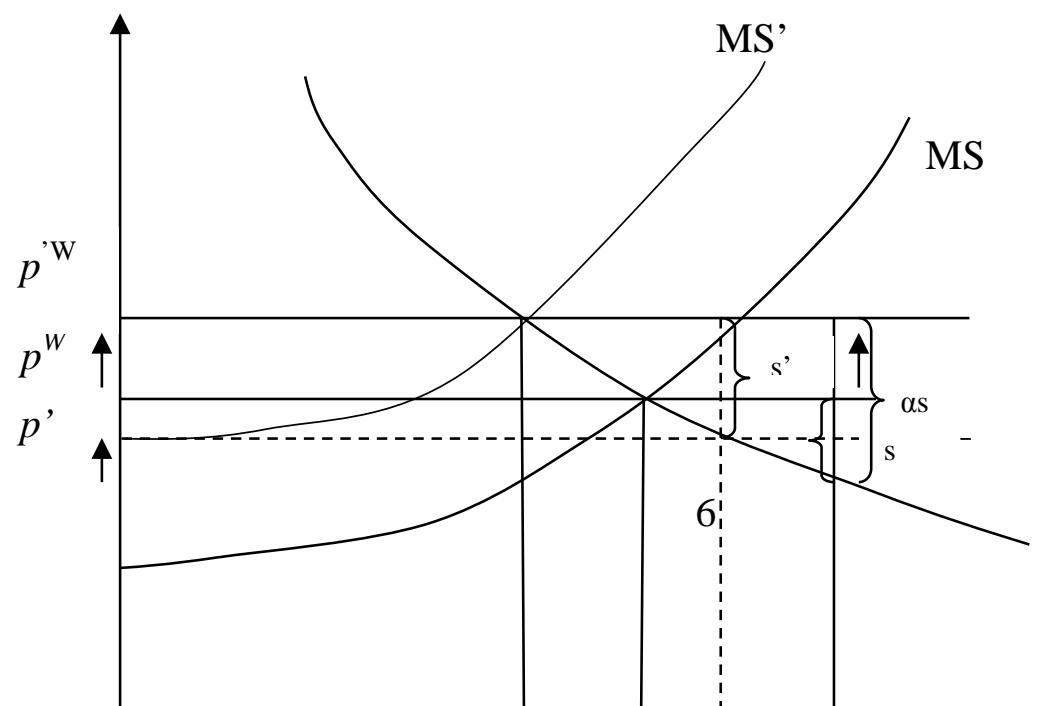




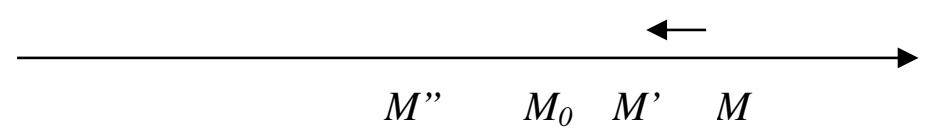

In the event of an international food price shock, the domestic import supply $M S$ shifts ${ }^{16}$ to $M S^{\prime}$ and the international food price jumps up from $p^{W}$ to $p^{W}$, where for convenience we assume that $d p^{W}=\alpha s$ or $\Delta p^{W}=\alpha s / p^{W}$ and $\alpha>0$. In this case, according to expression (5), the government will have to increase the subsidy paid per unit of imported food from $s$ to $(1+\alpha) s$ in order to keep the domestic price at $p$ and the quantity of imports at $M$. Increasing the subsidy will be possible in the absence of fiscal constraints. If there is a decline in the world food price $p^{W}$, the government will reduce the subsidy in order to keep the domestic food price $p$ stable. In the absence of a fiscal constraint, the flexible subsidy response to an international food price shock has a symmetric effect on the domestic price $p$ and keeps it constant.

However, as discussed above, an increase in the subsidy bill will be difficult to accommodate in economies with limited fiscal space, implying that domestic prices $p$ might have to increase. In our example, if the government does not have fiscal space to double the subsidy bill and must keep the fiscal burden associated with the subsidy unchanged, the domestic price $p$ will move up to $p$ ' and the quantity of imports will retreat from $M$ to $M^{\prime}$. The subsidy paid per unit of imported food will increase from $s$ to $s^{\prime}$, where $s^{\prime}=p^{W^{\prime}}-p^{\prime}$. The subsidy increase required to keep the fiscal burden constant is smaller than the one required to keep the domestic food price fixed at $p$, that is $s^{\prime}<(1+\alpha) s$. The subsidy increase and the increase in the domestic price depends on the shock to the world food price, $\Delta p^{W}$, the elasticity of the import demand curve, $M D$, and other factors that might affect import supply $M S$ and import demand $M D$.

If the world food price $p^{W}$ falls down towards the domestic price $p$, the government might decide to reduce subsidy $s$ per unit of imported food. This will have the effect of keeping the domestic food price stable at $p$ and the quantity of food imports at $M$. Thus, in the case of a government working under fiscal constraints, the subsidy response might have an asymmetric effect on domestic prices. Under asymmetric transmission, increases in world food prices are passed into domestic prices, pushing domestic food price levels up, but declines are rarely transmitted. 
In general, the causes of asymmetric price transmission are complex (Meyer and Cramon-Taubadel, 2004). They can be associated with factors other than fiscal constraints and rising subsidy costs. ${ }^{17}$ For example, there is evidence that adjustment issues at the wholesale and retail levels of distribution might be causing domestic prices to be downward sticky. Uncertainty of whether food price shocks are permanent or transitory, along with political uncertainty in some MENA economies, might also exacerbate market reluctance to respond to food price signals. Noncompetitive practices in the domestic or international markets might also contribute to an asymmetric response. Morisset (1998) finds that declines in world commodity prices are either not transmitted or transmitted only imperfectly into domestic consumer prices in developing countries precisely because of suspected uncompetitive practices. Thus, it is unclear a priori to what extent and how quickly world price fluctuations are transmitted to domestic food prices in MENA. The main factors that could influence the pass-through from world to domestic food prices are exchange rates, transport, and distribution costs, as well as domestic market distortions, including food subsidies.

\section{What Do the Data Tell Us?}

Historic monthly food price data for MENA are scarce and for most countries not readily available. For the 18 individual economies, we compiled monthly food consumer price data for the period from 2000 to 2011 from national statistical offices and complemented them, in some cases, with historical food price information from the International Labor Organization (ILO). The two exceptions were Lebanon, where the main data source was information collected by World Bank staff, and Iran, where we used food price data compiled by the Central Bank. Food prices from Iran's national statistical office and annual growth rates were much lower than those reported by the Central Bank. Libya was omitted from the analysis because of the absence of consistent information on domestic food prices. Monthly price observations were missing only in the cases of Algeria, Kuwait, Qatar, Bahrain, and Yemen. The missing values represented about $4.5 \%$ of the total observations for these countries. $^{18}$

We made efforts to ensure data accuracy by comparing trend and annual growth consistency of the different time-series from 2000 to 2011. We further corroborated the data with general market information from various press releases, 
field documentation from United States Department of Agriculture (USDA), and country updates by World Bank economists. In the cases of Djibouti, Jordan, Lebanon, and Tunisia, the level data in different series showed divergences from original series due to rebasing, yet the effects on annual growth rates were negligible.

We used the World Bank's Food Price Index to represent international food prices. The index consists of cereals with $28 \%$ share, followed by meals and vegetable oils with $41 \%$ share, and other food items, including sugar with 31\% share. Culturally sensitive items for Arab countries, such as pork meat or alcoholic beverages, are not included in this index. The focus on cereals, cooking oil, and sugar mirrors MENA domestic food price indices. Although it would have been better to have indexes with identical weights, we use the world and domestic food price pairs for transparency and data availability reasons. These indices are suitable to address how food prices shocks are transmitted into the domestic food market in general. They are not suitable to make assessments about specific commodities and food markets, which require analysis of individual commodity price pairs. Overall, because of the great emphasis on consistency checks with other than official sources, we believe the food price dataset provides accurate information on food price patterns for most MENA economies. However, any observed deviations from perfect pass-through and crosscountry differences in the pass-through coefficients will be due, at least in part, to differences in the extent to which national food baskets differ from the basket behind the global food price index and across countries, respectively.

In nearly all countries food inflation registered a peak in 2008, yet there are substantial differences in food inflation patterns across the Arab world, possibly reflecting country-specific idiosyncratic factors (see online Appendix Table A1). In most countries, average domestic food inflation remained lower than global food inflation, and in most Arab economies annual food inflation rates remained positive even during periods when international food inflation turned negative. This fact is consistent with asymmetric transmission of international food price fluctuations to domestic markets in the Arab world - a hypothesis investigated in the empirical section.

As a first attempt to understand the exposure of the MENA countries to global food price shocks, we use USDA data and calculate ratios of net imports to domestic consumption of key food commodities, together with their respective import and consumption shares, by country (Table 1) and country groupings (Table 2). The 
analysis covers grain and non-grain imports; the latter account for approximately half of all food imports in developing MENA (column 3, Table 2). In the GCC group of countries the share of grain imports in food imports is under $30 \%$.

The import food dependency ratios $D_{i}$ of net imports $M_{i}$ to domestic consumption $C_{i}$, presented in Table 1 and calculated as $D_{i}=M_{i} / C_{i}$, are indicative of the dependency on imports to satisfy domestic demand for food product $i$, where $i$ corresponds to grains, edible oils, meat, and sugar which represent the most important food products for MENA economies. A country-specific import food dependency ratio is obtained by computing the ratio of net total imports over total food consumption of the four food groups. The dependency ratios across country groupings are then aggregated using simple averages.

In all developing MENA economies, except Lebanon, grains account for the largest share in total food consumption, while in high-income GCC countries meat has the highest weight in the consumption basket (Table 1). In MENA, import food dependence is high except in Iran, and nearly complete (around or above 90\%) in all GCC economies, except Saudi Arabia where it is $80 \%$. Thus, in the absence of policies to soften the effect of world food price fluctuations, the pass-through effects from world to domestic prices should be largest in the GCC economies, as well as in some other countries, such as Yemen, Iraq, and Jordan.

To gauge the first-round effects of a sharp increase in key food prices we also compute the corresponding increase in the import bill as a share of the 2010 GDP and as a share of international reserves, excluding gold (Table 3). ${ }^{19}$ The analysis relies on USDA data for supply and demand of individual food commodities, World Bank international commodity prices, International Monetary Fund (IMF) data on international reserves, and World Bank data for the 2010 GDP by country.

The effect on the regional import bill of the global price increase during the period from June 2010 to July 2011 is estimated at $0.6 \%$ of GDP and 1.4\% of international reserves, with grains making the largest contribution, followed by edible oils, sugar, and meat (Table 3). Oil importers were hardest hit. The increase in their import bill is about $1.2 \%$ of GDP, with half of the increase attributed to the effect of higher grain prices. This is consistent with the high share of grains in their import basket (Table 2). The expected increase in the import bill of the developing oil exporters is estimated at $0.8 \%$ of GDP and $2.3 \%$ of international reserves, with more than half of this increase due to the rise in the prices of edible oils and sugar. These 
two products exert a large effect on the import bill despite their relatively small shares in the import basket because the dependence on imported edible oils and sugar is high. The overall effect on the GCC region is estimated to be $0.3 \%$ of GDP and $0.5 \%$ of international reserves, with the largest shock coming from the increase in sugar prices, reflecting a surge in sugar prices and high sugar import dependency (Table 2). In these countries, sugar is used not only for domestic consumption, but also as intermediate input into processed food exports.

The macroeconomic effects of high international food prices on GDP and international reserves are small for the GCC countries, given their small population and high per capita income. However, the effects are sizable for many other MENA countries, mainly because of the big role of grain imports for domestic consumption. This finding is consistent with MENA's high grain import dependency, the high grain import share, and the large increase in world grain prices compared with world meat prices. International prices of oils and sugar jumped, in some cases, by more than the prices of grains, but their lower share in imports implies a smaller effect on the import bill.

Table 1. Dependency, Import, and Consumption Shares for 2010 by Country 


\begin{tabular}{|c|c|c|c|c|c|c|c|}
\hline $\begin{array}{l}\text { Country / } \\
\text { Food Item }\end{array}$ & $\begin{array}{l}\text { Import } \\
\text { Dependency } \\
\text { Shares }\end{array}$ & $\begin{array}{l}\text { Commodity } \\
\text { Import } \\
\text { Shares }\end{array}$ & $\begin{array}{l}\text { Commodity } \\
\text { Consumption } \\
\text { Shares }\end{array}$ & $\begin{array}{l}\text { Country / } \\
\text { Food Item }\end{array}$ & $\begin{array}{l}\text { Net Imports } \\
\text { As a Share of } \\
\text { Consumption }\end{array}$ & $\begin{array}{l}\text { Commodity } \\
\text { Import } \\
\text { Shares }\end{array}$ & $\begin{array}{l}\text { Commodity } \\
\text { Consumption } \\
\text { Shares }\end{array}$ \\
\hline Algeria & & & & Lebanon & & & \\
\hline Grains & $68 \%$ & $52 \%$ & $52 \%$ & Grains & $87 \%$ & $39 \%$ & $32 \%$ \\
\hline Oils & $88 \%$ & $22 \%$ & $18 \%$ & Oils & $38 \%$ & $7 \%$ & $8 \%$ \\
\hline Meat & $33 \%$ & $7 \%$ & $15 \%$ & Meat & $56 \%$ & $38 \%$ & $49 \%$ \\
\hline Sugar & $89 \%$ & $19 \%$ & $15 \%$ & Sugar & $100 \%$ & $16 \%$ & $11 \%$ \\
\hline Food & $69 \%$ & $100 \%$ & $100 \%$ & Food & $70 \%$ & $100 \%$ & $100 \%$ \\
\hline Bahrain & & & & Morocco & & & \\
\hline Grains & $100 \%$ & $28 \%$ & $25 \%$ & Grains & $51 \%$ & $57 \%$ & $61 \%$ \\
\hline Oils & $\mathrm{n} / \mathrm{a}$ & $\mathrm{n} / \mathrm{a}$ & $\mathrm{n} / \mathrm{a}$ & Oils & $59 \%$ & $24 \%$ & $21 \%$ \\
\hline Meat & $88 \%$ & $62 \%$ & $65 \%$ & Meat & $\mathrm{n} / \mathrm{a}$ & $\mathrm{n} / \mathrm{a}$ & $\mathrm{n} / \mathrm{a}$ \\
\hline Sugar & $100 \%$ & $10 \%$ & $9 \%$ & Sugar & $57 \%$ & $19 \%$ & $18 \%$ \\
\hline Food & $92 \%$ & $100 \%$ & $100 \%$ & Food & $54 \%$ & $100 \%$ & $100 \%$ \\
\hline Egypt & & & & Oman & & & \\
\hline Grains & $39 \%$ & $54 \%$ & $62 \%$ & Grains & $91 \%$ & $26 \%$ & $24 \%$ \\
\hline Oils & $78 \%$ & $27 \%$ & $14 \%$ & Oils & $93 \%$ & $27 \%$ & $18 \%$ \\
\hline Meat & $37 \%$ & $10 \%$ & $13 \%$ & Meat & $88 \%$ & $37 \%$ & $45 \%$ \\
\hline Sugar & $37 \%$ & $9 \%$ & $11 \%$ & Sugar & $85 \%$ & $10 \%$ & $12 \%$ \\
\hline Food & $44 \%$ & $100 \%$ & $100 \%$ & Food & $89 \%$ & $100 \%$ & $100 \%$ \\
\hline Iran & & & & Saudi Arabi & & & \\
\hline Grains & $19 \%$ & $32 \%$ & $46 \%$ & Grains & $85 \%$ & $35 \%$ & $34 \%$ \\
\hline Oils & $80 \%$ & $28 \%$ & $11 \%$ & Oils & $95 \%$ & $12 \%$ & $10 \%$ \\
\hline Meat & $23 \%$ & $24 \%$ & $34 \%$ & Meat & $57 \%$ & $33 \%$ & $46 \%$ \\
\hline Sugar & $61 \%$ & $17 \%$ & $9 \%$ & Sugar & $151 \%$ & $20 \%$ & $11 \%$ \\
\hline Food & $31 \%$ & $100 \%$ & $100 \%$ & Food & $80 \%$ & $100 \%$ & $100 \%$ \\
\hline Iraq & & & & Syria & & & \\
\hline Grains & $71 \%$ & $56 \%$ & $58 \%$ & Grains & $51 \%$ & $53 \%$ & $62 \%$ \\
\hline Oils & $100 \%$ & $9 \%$ & $7 \%$ & Oils & $6 \%$ & $7 \%$ & $19 \%$ \\
\hline Meat & $62 \%$ & $20 \%$ & $25 \%$ & Meat & $\mathrm{n} / \mathrm{a}$ & $\mathrm{n} / \mathrm{a}$ & $\mathrm{n} / \mathrm{a}$ \\
\hline Sugar & $104 \%$ & $15 \%$ & $11 \%$ & Sugar & $126 \%$ & $40 \%$ & $19 \%$ \\
\hline Food & $75 \%$ & $100 \%$ & $100 \%$ & Food & $56 \%$ & $100 \%$ & $100 \%$ \\
\hline Jordan & & & & Tunisia & & & \\
\hline Grains & $97 \%$ & $42 \%$ & $35 \%$ & Grains & $68 \%$ & $58 \%$ & $63 \%$ \\
\hline Oils & $68 \%$ & $17 \%$ & $20 \%$ & Oils & $-73 \%$ & $15 \%$ & $22 \%$ \\
\hline Meat & $25 \%$ & $27 \%$ & $34 \%$ & Meat & $\mathrm{n} / \mathrm{a}$ & $\underline{\mathrm{n} / \mathrm{a}}$ & $\mathrm{n} / \mathrm{a}$ \\
\hline Sugar & $98 \%$ & $14 \%$ & $11 \%$ & Sugar & $104 \%$ & $27 \%$ & $16 \%$ \\
\hline Food & $67 \%$ & $100 \%$ & $100 \%$ & Food & $43 \%$ & $100 \%$ & $100 \%$ \\
\hline Kuwait & & & & United Arab & b Emirates & & \\
\hline Grains & $101 \%$ & $25 \%$ & $26 \%$ & Grains & $100 \%$ & $18 \%$ & $22 \%$ \\
\hline Oils & $100 \%$ & $3 \%$ & $3 \%$ & Oils & $82 \%$ & $19 \%$ & $19 \%$ \\
\hline Meat & $86 \%$ & $67 \%$ & $66 \%$ & Meat & $87 \%$ & $24 \%$ & $51 \%$ \\
\hline Sugar & $100 \%$ & $6 \%$ & $6 \%$ & Sugar & $82 \%$ & $40 \%$ & $8 \%$ \\
\hline Food & $91 \%$ & $100 \%$ & $100 \%$ & Food & $89 \%$ & $100 \%$ & $100 \%$ \\
\hline \multicolumn{8}{|l|}{ Yemen } \\
\hline Grains & $84 \%$ & $54 \%$ & $55 \%$ & & & & \\
\hline Oils & $100 \%$ & $8 \%$ & $7 \%$ & & & & \\
\hline Meat & $43 \%$ & $10 \%$ & $20 \%$ & & & & \\
\hline Sugar & $104 \%$ & $27 \%$ & $18 \%$ & & & & \\
\hline Food & $81 \%$ & $100 \%$ & $100 \%$ & & & & \\
\hline
\end{tabular}

Table 2. Dependency, Import, and Consumption Shares in 2010 


\begin{tabular}{|c|c|c|c|c|c|c|c|}
\hline $\begin{array}{l}\text { Country / } \\
\text { Food Item }\end{array}$ & $\begin{array}{l}\text { Import } \\
\text { Dependency } \\
\text { Shares }\end{array}$ & $\begin{array}{l}\text { Commodity } \\
\text { Import } \\
\text { Shares }\end{array}$ & $\begin{array}{l}\text { Commodity } \\
\text { Consumption } \\
\text { Shares }\end{array}$ & $\begin{array}{l}\text { Country / } \\
\text { Food Item }\end{array}$ & $\begin{array}{l}\text { Net Imports } \\
\text { As a Share of } \\
\text { Consumption }\end{array}$ & $\begin{array}{l}\text { Commodity } \\
\text { Import } \\
\text { Shares }\end{array}$ & $\begin{array}{l}\text { Commodity } \\
\text { Consumption } \\
\text { Shares }\end{array}$ \\
\hline \multicolumn{4}{|c|}{ Developing Oil Exporters } & \multicolumn{4}{|c|}{ Gulf Cooperation Council } \\
\hline Grains & $44 \%$ & $46 \%$ & $51 \%$ & Grains & $89 \%$ & $28 \%$ & $30 \%$ \\
\hline Oils & $72 \%$ & $18 \%$ & $12 \%$ & Oils & $91 \%$ & $14 \%$ & $14 \%$ \\
\hline Meat & $30 \%$ & $15 \%$ & $31 \%$ & Meat & $69 \%$ & $34 \%$ & $49 \%$ \\
\hline Sugar & $87 \%$ & $21 \%$ & $12 \%$ & Sugar & $132 \%$ & $25 \%$ & $10 \%$ \\
\hline Food & $49 \%$ & $100 \%$ & $100 \%$ & Food & $83 \%$ & $100 \%$ & $100 \%$ \\
\hline \multicolumn{4}{|l|}{ MENA } & \multicolumn{4}{|c|}{ Oil Importers } \\
\hline Grains & $48 \%$ & $44 \%$ & $51 \%$ & Grains & $46 \%$ & $53 \%$ & $59 \%$ \\
\hline Oils & $69 \%$ & $19 \%$ & $15 \%$ & Oils & $60 \%$ & $24 \%$ & $16 \%$ \\
\hline Meat & $42 \%$ & $18 \%$ & $29 \%$ & Meat & $38 \%$ & $10 \%$ & $20 \%$ \\
\hline Sugar & $78 \%$ & $19 \%$ & $12 \%$ & Sugar & $53 \%$ & $13 \%$ & $12 \%$ \\
\hline Food & $53 \%$ & $100 \%$ & $100 \%$ & Food & $48 \%$ & $100 \%$ & $100 \%$ \\
\hline
\end{tabular}

Table 3. Changes in Import Bill due to World Food Price Increases in 2010

\begin{tabular}{|c|c|c|c|}
\hline & & $\%$ of 2010 GDP & $\begin{array}{c}\text { \% of international } \\
\text { reserves }\end{array}$ \\
\hline \multirow[t]{5}{*}{ MENA } & Food & 0.62 & 1.44 \\
\hline & Grains & 0.27 & 0.63 \\
\hline & Oils & 0.17 & 0.4 \\
\hline & Meat & 0.04 & 0.09 \\
\hline & Sugar & 0.14 & 0.32 \\
\hline \multirow[t]{5}{*}{ Gulf Cooperation Council } & Food & 0.25 & 0.45 \\
\hline & Grains & 0.07 & 0.12 \\
\hline & Oils & 0.06 & 0.12 \\
\hline & Meat & 0.02 & 0.04 \\
\hline & Sugar & 0.09 & 0.17 \\
\hline \multirow[t]{5}{*}{ Developing oil exporters } & Food & 0.78 & 2.28 \\
\hline & Grains & 0.33 & 0.98 \\
\hline & Oils & 0.22 & 0.61 \\
\hline & Meat & 0.05 & 0.14 \\
\hline & Sugar & 0.19 & 0.55 \\
\hline \multirow[t]{5}{*}{ Oil importers } & Food & 1.15 & 4.39 \\
\hline & Grains & 0.59 & 2.32 \\
\hline & Oils & 0.35 & 1.23 \\
\hline & Meat & 0.05 & 0.24 \\
\hline & Sugar & 0.15 & 0.59 \\
\hline
\end{tabular}

This analysis gives an idea about the relative importance of different food commodities for macroeconomic indicators such as aggregate imports, yet it ignores second-round effects and may heavily misrepresent the influence on consumer prices, which can vary significantly due to individual country characteristics and policies. Domestic price levels can be affected not only by world food price movements, but 
also by a number of country-specific factors, including exchanges rates, domestic policies, such as food price controls and subsidies, trade and production policies, and food stock management, as well as other domestic issues related to supply chain management, infrastructure, weather patterns, and other factors. For these reasons, just looking at food dependency ratios will not reveal the extent to which international food price movements are transmitted to domestic food prices. The degree of international food price transmission is analysed next.

\section{Econometric Approach}

We first test for co-integration and fail to find evidence for co-integrating vector among domestic and international food prices at conventional significance levels. The Augmented Dickey Fuller (ADF) Unit Root Tests and co-integration analysis are presented in online Appendix Tables A2 and A3, respectively. We associate these results with our conceptual model, presented in section 2, which argues that food price volatility, distortions in domestic and international food markets, and in particular the existence of food subsidies in combination with fiscal constraints can create an unstable price policy regime. In this situation standard co-integration analysis will not be an effective approach. ${ }^{20}$ Hence, in line with our conceptual model, we find that a VAR modeling choice is appropriate, at least for the period under consideration, as it allows us to analyze effectively short-run variations in international and domestic food prices.

As a baseline for the calculations of the pass-through effects, we consider the following autoregressive model that explicitly focuses on the short-run correlations between international and domestic food prices:

$$
\Delta p_{t}=\alpha+\sum_{i=1}^{k} \beta_{i} \Delta p_{t-i}+\sum_{i=1}^{k} \gamma_{i} \Delta \mathrm{p}_{\mathrm{t}-\mathrm{i}}^{\mathrm{W}}+\sum_{i=1}^{k} \delta_{i}^{p} \Delta e_{t-i}+\varepsilon_{t},
$$

where $\Delta p$ is the annual percentage change of the domestic food consumer price index, $\Delta p_{t-i}$ represents lagged annual percentage changes of the domestic food prices, and helps account for domestic factors and expectations, and $p_{t-i}^{W}$ is the annual percentage change of the World Bank's international food price index, which is calculated from food prices measured in current US\$. In addition, exchange rate shocks might be important in determining domestic inflation. If the domestic currency depreciates (appreciates), international food price increases will have a stronger (weaker) pass- 
through effect. This is a significant consideration because some of the inflationary effects could be due to currency movements rather than changes in world food prices. We control for lagged growth rates in the domestic exchange rates $e$ vis-à-vis the US dollar as a significant share of food imports is denominated in US dollars. The nominal effective exchange rate, which is a trade-weighted average of nominal exchange rates, might not be a good proxy for import prices because it also contains export data.

We also take advantage of findings on food price transmission (Meyer and Cramon-Taubadel, 2004; Peltzman, 2000; Vavra and Goodwin, 2005) and consider increases and decreases in commodity prices as separate variables. Thus, the baseline model in equation (6) is transformed into a threshold regression, which allows us to determine whether the transmission is asymmetric and the extent of asymmetry:

$$
\Delta p_{t}=\alpha+\sum_{i=1}^{k} \beta_{i} \Delta p_{t-i}+ \begin{cases}\sum_{i=1}^{k} \gamma_{i}^{p} \Delta p_{t-i}^{W}+\sum_{i=1}^{k} \delta_{i}^{p} \Delta e_{t-i} & \text { if } \Delta p_{t-1}^{W} \geq 0 \\ \sum_{i=1}^{k} \gamma_{i}^{n} \Delta p_{t-i}^{W}+\sum_{i=1}^{k} \delta_{i}^{n} \Delta e_{t-i} & \text { if } \Delta p_{t-1}^{W}<0\end{cases}
$$

To facilitate a consistent interpretation across countries, we derive estimates of the 6 and 12-month pass-through effects from cumulative impulse response functions. ${ }^{21}$ The coefficients show the models' predicted adjustment of domestic food prices to changes in world food prices, controlling for the exchange rate and domestic factors. In most economies, the food price pass-through effects fade out after about one year or, in other words, the partial transmission of the international food price shock is completed during the course of a year.

We allow for lags when estimating the models. The cumulative lag structure is chosen to minimize the Akaike Information Criterion (AIC) and by Wald lag exclusion tests. The optimal lag length is found to be $k=12$ for most countries. In some cases (Lebanon, Djibouti, Yemen, Syria, Iraq, Oman, Qatar, and the UAE) the test suggests the use of shorter lags. We control for seasonal factors by estimating the model in annual growth rates and sparsely employ impulse dummies to correct for extreme jumps in domestic food prices, for instance, due to religious holidays, specific national events, or weather effects. ${ }^{22}$ We also use time trends when significant to capture other unknown exogenous factors on domestic prices. Summary statistics from the regressions are presented in the online Appendix Table A4. Next, 
we discuss the main results derived from impulse response functions and variance decompositions.

\section{Empirical Results}

\section{Pass-Through Coefficients}

The dynamics and magnitude of the food price pass-through effects vary by country (Table 4). International food price shocks are a risk for many Arab economies despite food subsidies. ${ }^{23}$ Food price shocks transmit partially into MENA economies as they do in other countries around the world. The strongest pass-through effects are found in the West Bank and Gaza (WBG), Djibouti, Iraq, Egypt, and the UAE. In these economies, the pass-through coefficients are above 0.4, indicating partial transmission but higher vulnerability to world food price shocks than observed elsewhere in MENA. The large majority of economies have food price pass-through elasticities in the order of 0.2-0.4. Algeria and Tunisia have lowest pass-through elasticities in the region.

To get a sense of the robustness of these estimates, we used Monte Carlo simulations (1,000 iterations) and bootstrap standard errors for the 6-month and 12month food price pass-through coefficients (Table 4). In most cases, the estimated 12month pass-through elasticities are statistically significant at the 5\% level. The passthrough coefficients are not significant in the cases of Algeria, Tunisia, and Saudi Arabia possibly due to policy interventions, which limit price transmission. In the cases of Lebanon, Oman, and Yemen this is due to relatively short time-series which render the coefficients insignificant.

We also tested the robustness of the results to the choice of the food price index. We used the United Nations Food and Agricultural Organisation (FAO) world food price index as an alternative to the World Bank's food price index. Both indices are similar, but the FAO index shows higher peaks in 2011. The standard errors of the coefficients increased, but the pass-through coefficients were preserved when we used the FAO index. We obtained lower pass-through coefficients when we used disaggregate world price index data for cereals from FAO and the World Bank rather than the aggregated indices. This result is consistent with the fact that most government subsidies are concentrated on grains. The results do not change when we use the euro as the main nominal effective reference exchange rate. We prefer to use 
the US dollars as the prices underpinning the international food price index are expressed in this currency.

Table 4. Summary of Food Price Pass-Through Coefficients by Country (Cumulative Impulse Responses)

\begin{tabular}{|c|c|c|c|c|c|}
\hline \multirow{2}{*}{\multicolumn{2}{|c|}{ Country and group }} & \multicolumn{2}{|c|}{ 6-month food price pass-through } & \multicolumn{2}{|c|}{ 12-month food price pass-through } \\
\hline & & World price increase & World price decrease & World price increase & World price decrease \\
\hline \multirow{12}{*}{ 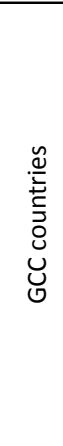 } & \multirow[t]{2}{*}{ Bahrain } & 0.050 & 0.057 & 0.349 & 0.051 \\
\hline & & $(0.057)$ & $(0.036)$ & $(0.113)$ & $(0.034)$ \\
\hline & \multirow[t]{2}{*}{ Kuwait } & 0.107 & 0.016 & 0.279 & 0.020 \\
\hline & & $(0.081)$ & $(0.029)$ & $(0.128)$ & $(0.029)$ \\
\hline & \multirow[t]{2}{*}{ Oman } & 0.341 & 0.079 & 0.213 & 0.075 \\
\hline & & $(0.142)$ & $(0.063)$ & $(0.130)$ & $(0.074)$ \\
\hline & \multirow[t]{2}{*}{ Qatar } & 0.286 & 0.182 & 0.355 & 0.220 \\
\hline & & $(0.125)$ & $(0.085)$ & $(0.161)$ & $(0.099)$ \\
\hline & \multirow[t]{2}{*}{ Saudi Arabia } & 0.144 & 0.033 & 0.266 & 0.023 \\
\hline & & $(0.278)$ & $(0.024)$ & $(0.232)$ & $(0.021)$ \\
\hline & \multirow[t]{2}{*}{ UAE } & 0.355 & 0.298 & 0.413 & 0.315 \\
\hline & & $(0.178)$ & $(0.143)$ & $(0.202)$ & $(0.163)$ \\
\hline \multirow{10}{*}{ 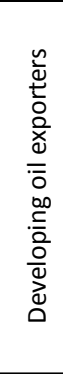 } & \multirow[t]{2}{*}{ Algeria } & 0.065 & 0.066 & 0.059 & 0.048 \\
\hline & & $(0.077)$ & $(0.048)$ & $(0.072)$ & $(0.037)$ \\
\hline & \multirow[t]{2}{*}{ Iran } & 0.103 & 0.003 & 0.282 & 0.052 \\
\hline & & $(0.081)$ & $(0.026)$ & $(0.116)$ & $(0.043)$ \\
\hline & \multirow[t]{2}{*}{ Iraq } & 0.122 & 0.062 & 0.497 & 0.055 \\
\hline & & $(0.131)$ & (0.083) & (0.158) & $(0.100)$ \\
\hline & \multirow[t]{2}{*}{ Syria } & 0.163 & 0.052 & 0.261 & 0.100 \\
\hline & & $(0.097)$ & $(0.053)$ & $(0.114)$ & $(0.067)$ \\
\hline & \multirow[t]{2}{*}{ Yemen } & 0.393 & 0.147 & 0.311 & 0.234 \\
\hline & & $(0.161)$ & (0.177) & $(0.166)$ & (0.192) \\
\hline \multirow{14}{*}{ 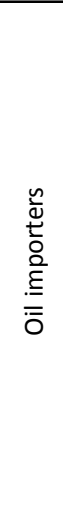 } & \multirow[t]{2}{*}{ Djibouti } & 0.583 & 0.037 & 0.464 & 0.129 \\
\hline & & $(0.180)$ & $(0.078)$ & $(0.183)$ & $(0.106)$ \\
\hline & \multirow[t]{2}{*}{ Egypt } & 0.336 & 0.041 & 0.441 & 0.034 \\
\hline & & $(0.124)$ & $(0.032)$ & $(0.140)$ & $(0.031)$ \\
\hline & \multirow[t]{2}{*}{ Jordan } & 0.219 & 0.054 & 0.392 & 0.130 \\
\hline & & $(0.102)$ & $(0.047)$ & $(0.118)$ & $(0.069)$ \\
\hline & \multirow[t]{2}{*}{ Lebanon } & 0.080 & 0.145 & 0.180 & 0.132 \\
\hline & & $(0.172)$ & $(0.096)$ & $(0.209)$ & $(0.093)$ \\
\hline & \multirow[t]{2}{*}{ Morocco } & 0.044 & 0.061 & 0.394 & 0.052 \\
\hline & & $(0.063)$ & $(0.050)$ & $(0.121)$ & $(0.042)$ \\
\hline & \multirow[t]{2}{*}{ Tunisia } & 0.070 & 0.004 & 0.058 & 0.005 \\
\hline & & $(0.092)$ & $(0.022)$ & $(0.092)$ & $(0.025)$ \\
\hline & \multirow[t]{2}{*}{ WBG } & 0.475 & 0.015 & 0.658 & 0.017 \\
\hline & & $(0.123)$ & $(0.034)$ & $(0.134)$ & $(0.040)$ \\
\hline
\end{tabular}

Note: Bootstrapped standard errors in parenthesis; bold numbers indicate significance at the $5 \%$ level or better.

A decline in international food prices does not transmit into domestic food markets and in virtually all MENA countries food prices are highly downward-sticky. Commodity price volatility thus has an asymmetric effect on domestic prices: only price increases are transmitted, whereas price declines are not. These results are confirmed by a Wald test for statistical difference between the positive and negative cumulative transmission coefficients (Table 5). The test provides strong evidence for asymmetry in most cases, except UAE and Yemen. ${ }^{24}$ In the cases of Syria, Algeria, 
and Tunisia, the evidence for asymmetry is weak possibly due to the low pass-through elasticities. These results are consistent with the findings of FAO (2009) and Moghaddasi (2009), ${ }^{25}$ and the discussion of food subsidies in section 2.

Table 5. Food Price Transmission Asymmetry Tests

\begin{tabular}{lcccrr}
\hline \multicolumn{2}{c}{ X2 statistics Wald test: $\delta^{+}=\delta^{-}$} \\
\hline \multicolumn{2}{c}{ GCC Economies } & \multicolumn{2}{c}{ Developing Oil Exporters } & \multicolumn{2}{c}{ Oil Importers } \\
\hline Bahrain & $\mathbf{1 2 . 9 6}$ & Algeria & 3.19 & Djibouti & 9.59 \\
Kuwait & $\mathbf{3 1 . 7 1}$ & Iran & $\mathbf{2 2 . 4 8}$ & Egypt & $\mathbf{3 3 . 8 9}$ \\
Oman & $\mathbf{2 2 . 6 4}$ & Iraq & $\mathbf{1 2 . 1 3}$ & Jordan & $\mathbf{2 4 . 2 8}$ \\
Qatar & $\mathbf{1 6 . 9 8}$ & Syria & 6.14 & Lebanon & 9.97 \\
Saudi Arabia & $\mathbf{3 4 . 5 7}$ & Yemen & 0.04 & Morocco & $\mathbf{1 1 . 8 2}$ \\
UAE & 0.01 & & & Tunisia & 7.56 \\
& & & & WBG & $\mathbf{2 5 . 3 9}$ \\
\hline
\end{tabular}

Note: Bold numbers indicate significance at the $5 \%$ level or better.

\section{Dynamics of Food Price Transmission}

To get insights into the dynamics of price transmission, we plot cumulative impulse response functions of a $1 \%$ increase in international food prices over a 12-month window. The results suggest that the partial transmission typically takes less than one year to complete and in many cases it is already apparent after about 3-6 months, but the speed of transmission varies across countries (Figure 3).

Djibouti, one of the poorest countries in the region with a fragile food security situation, has the strongest pass-through effects both in terms of magnitude and transmission speed. Similarly, the food price transmission in the West Bank and Gaza is strong, reaching $0.4 \%$ after 4 months and above $0.6 \%$ after 12 months. In Yemen, the pass-through effect reaches a peak of about $0.4 \%$ after 5 months. High rates of food insecurity and import dependency might explain the rapid transmission there (Table 1). In Egypt, the food price pass-through is significant and visible after a few months and peaks at about $0.4 \%$ after about 10 months. In Jordan, food price transmission starts to pick-up after about 6 months, but the overall effect after one year is similar to that in Egypt. The relatively slow transmission reflects the combined effect of government interventions, such as consumer price subsidies and controls, release of grain reserves, and tax reductions of several agricultural inputs, including fuel. Without these measures the pass-through effect would be stronger given Jordan's near complete dependency on imports of grains, sugar, meat, and oils (Table 1). In Morocco, the pace of the food price transmission typically builds up after 8 months, 
reaching magnitudes similar to those observed for Egypt and Jordan. The delay in transmission can be attributed to several factors, including the use of subsidies to regulate domestic food prices, suspension of customs duties on cereal imports, suspension of local tax collection targeting fresh food traded in wholesale markets, and price control operations to contain price increases resulting from speculation. In Iraq, the pass-through process is relatively slow during the first 6 months, but speeds up after that. A 1\% increase of world food prices increases domestic prices there by almost 0.5\%. In Lebanon, high subsidies for food and fuel (Albers and Peeters, 2011) help to explain the relatively slow pace of transmission and mild pass-through effects. In Tunisia, the small food price pass-through effects reflect price controls and food subsidies. In Iran, the slow pace of food price transmission can be attributed to lower import food dependency (Table 1) and the presence of subsidies. ${ }^{26}$ World price shocks are not significantly transmitted to domestic food markets in Algeria, likely because of food price controls, subsidies, and other interventions.

In most GCC economies, the pass-through effects become visible after about 7 months. ${ }^{27}$ The relatively slow transmission process in the GCC countries is consistent with the fact that these countries have fiscal space to support stable food prices through subsidy programs and other measures. Without such policies transmission would be much faster and stronger, given the nearly complete dependence on imports of grains and other major food commodities (Table 1).

Most MENA countries have been affected by the food prices increases in global markets since the 2006 global food crisis (Figure 4). With the exception of Morocco, all countries have seen an increase in their domestic food prices by more than 20\%, but Djibouti and Egypt registered extreme food price increases. Yet, other factors played a role too. The variance decompositions, presented in Figure 4, show the contributions in percentage points of the different factors influencing the domestic food price change during the period from December 2006 to June $2011 .{ }^{28}$ Consistent with the discussion in the previous section, the estimates suggest that rising world food prices have been a major factor behind the increase in domestic food prices. The increase in world food prices typically explains some $20-30 \%$ of the variation in domestic prices. International prices have been a particularly strong driver of food inflation in Iraq and West Bank and Gaza, where they accounted for over $50 \%$ of food inflation, followed by Egypt, Djibouti, and the UAE, where they contributed some $40 \%$ to food inflation. 
Figure 3. MENA Countries’ Food Price Pass-through Dynamics

Djibouti

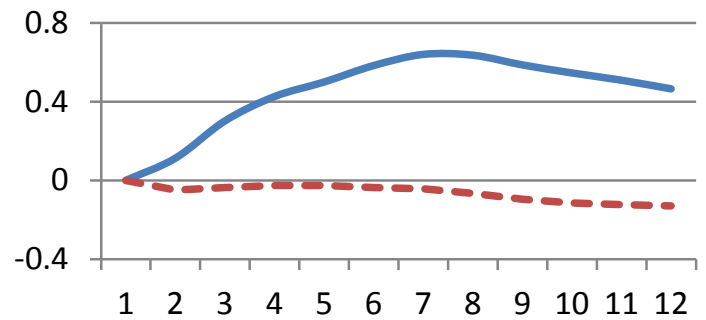

Jordan

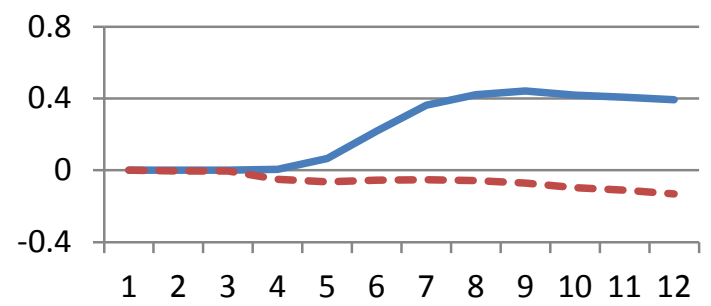

Morocco

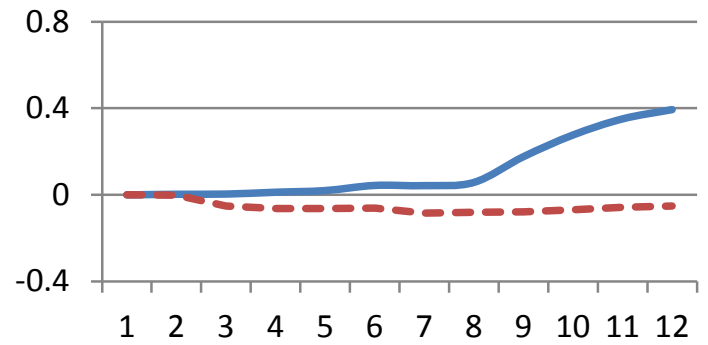

West Bank and Gaza

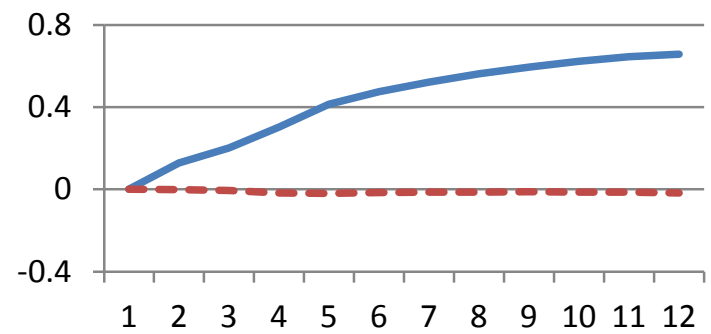

Egypt

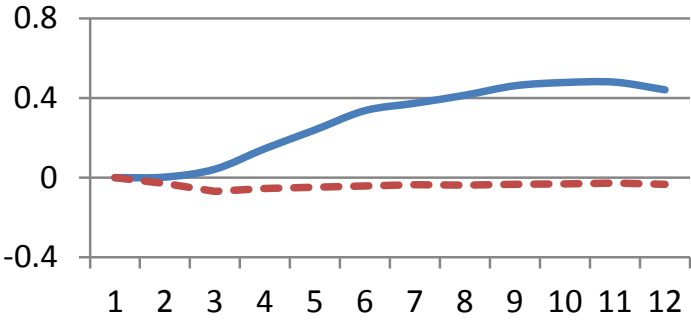

Lebanon

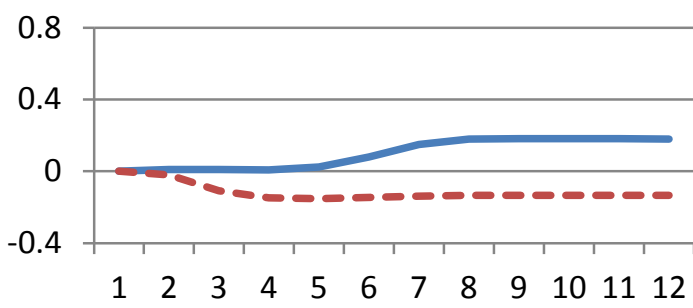

Tunisia

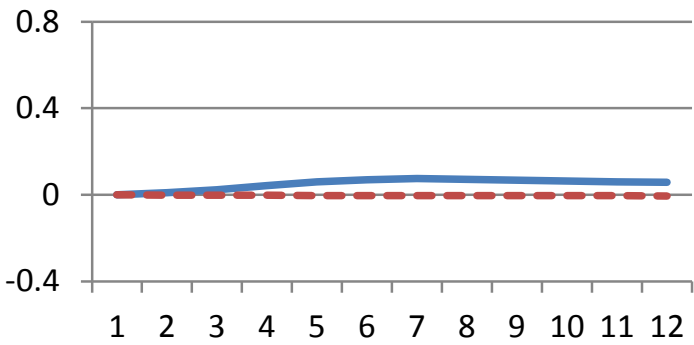

Yemen

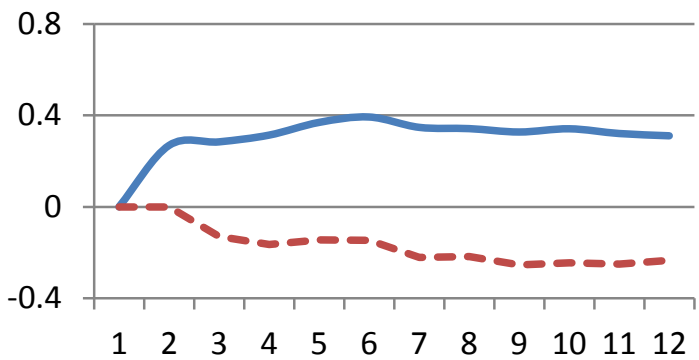

Figure 3 (contd.) MENA Countries' Food Price Pass-through Dynamics

Algeria Iran 

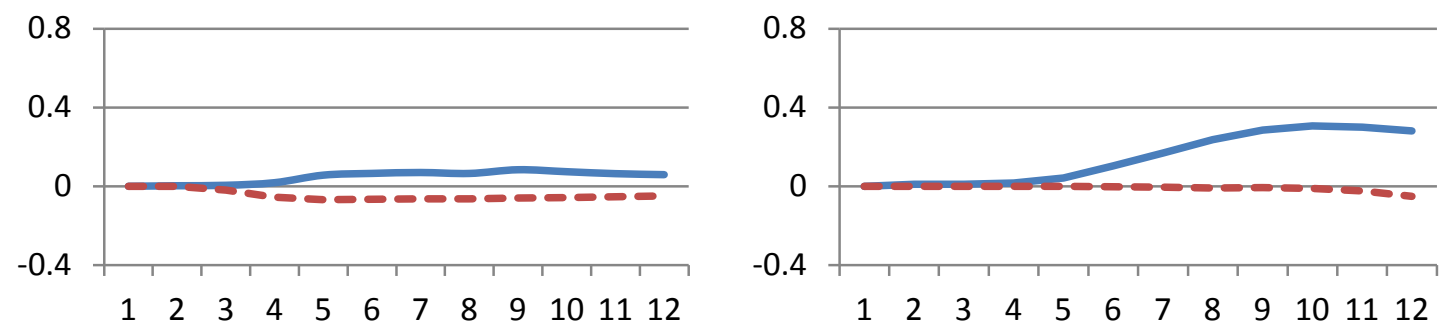

Iraq

Syria
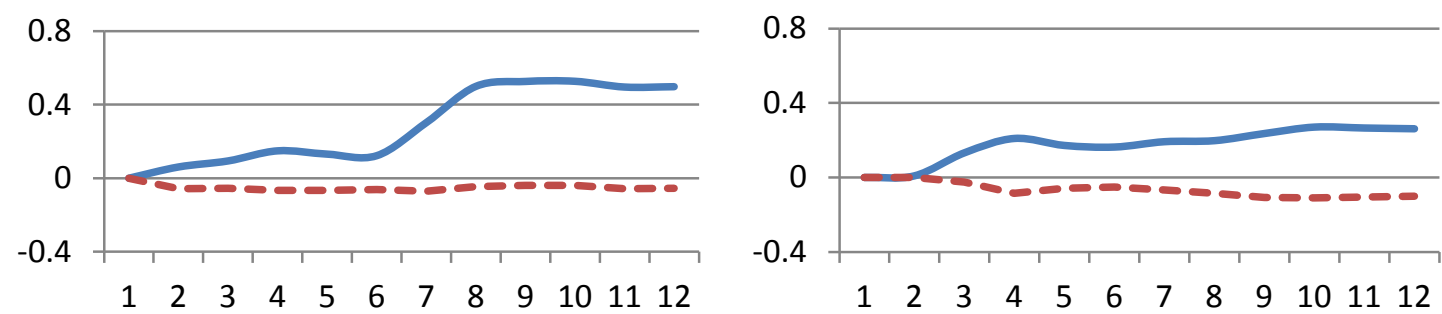

Bahrain

Kuwait
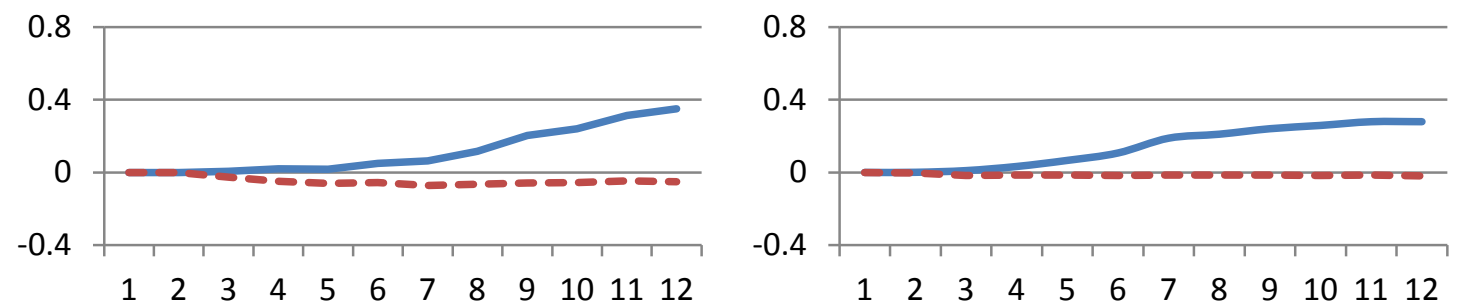

Qatar

Oman
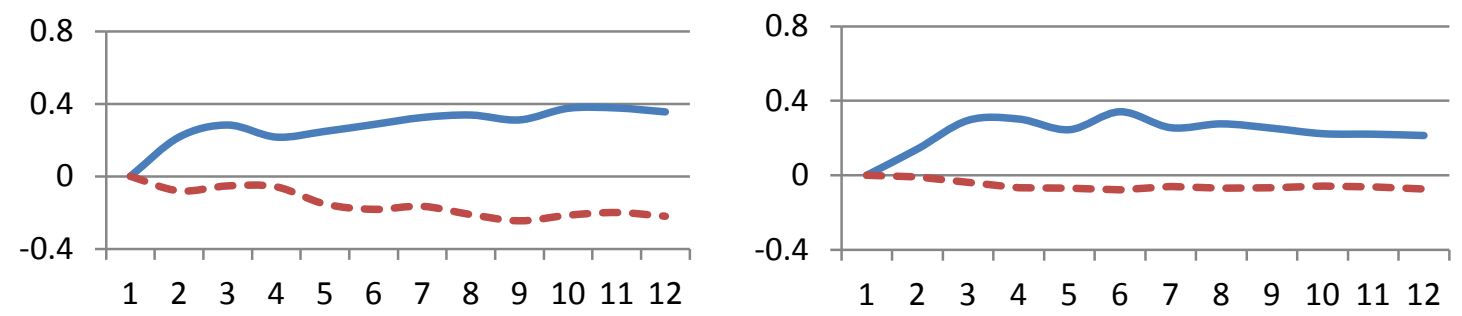

Figure 3 (contd.) MENA Countries’ Food Price Pass-through Dynamics UAE Saudi Arabia 

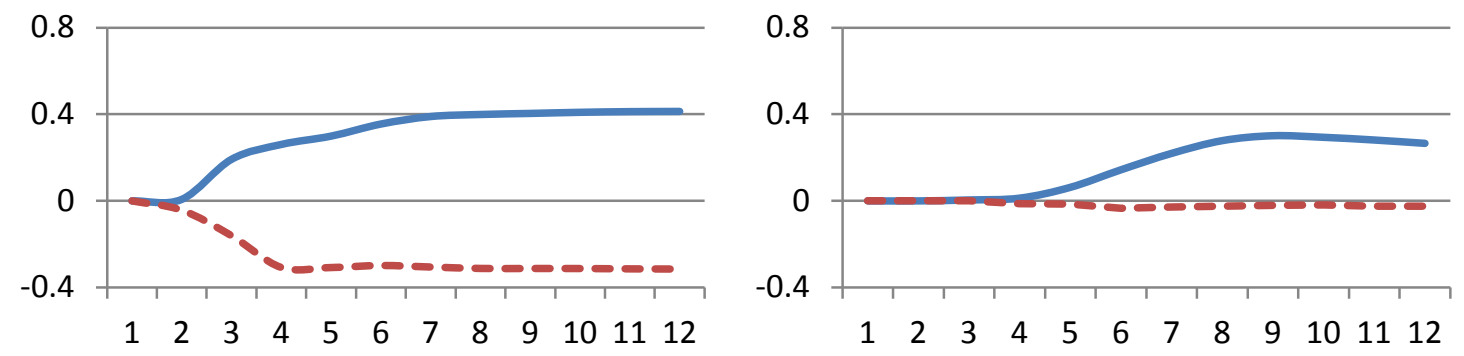

Note: The figure shows the percentage change in domestic food prices for a $1 \%$ increase (shown as a solid line) and for a 1\% decrease (shown as a dashed line) in world food prices over a 12-month window based on impulse response functions.

Figure 4. Variance Decomposition of Accumulated Domestic Food Price Increases between December 2006 and June 2011 (x-axis in percentage points)

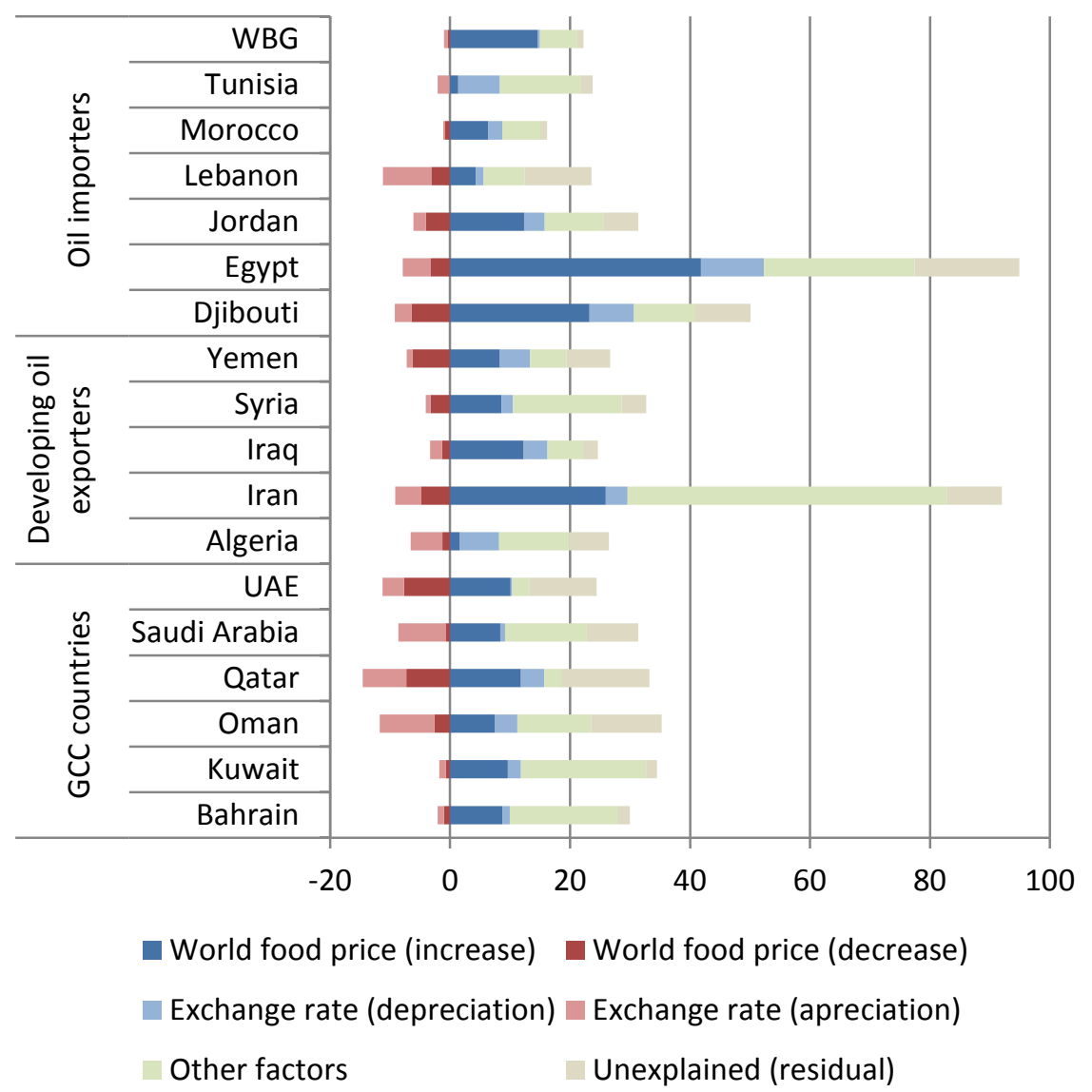

Exchange rate depreciation has played a minor role in most countries, except Tunisia and Yemen, where the nominal exchange rate has depreciated by more than 8\% vis-à-vis the US dollar and by more than 14\% vis-à-vis the euro since 2006. Domestic factors, notably inflexible procurement and poor logistics, have also played a major role in explaining domestic food inflation in nearly all MENA economies. For example, a World Bank (2012) report argues that countries could generate significant 
cost savings by improving the efficiency of the wheat import supply chain. Evidence suggests that it takes on average 4 times longer and costs 3.5 times more to import wheat in an Arab country than in the Netherlands. However, there are significant differences in supply chain performance across the MENA region, with some economies having bottlenecks at the port, while others having inefficient inland transportation systems.

\section{Concluding Remarks}

Our estimates suggest that international food price shocks are transmitted to various degrees into domestic markets. The magnitude of the estimates appears to be in line with the empirical evidence for other countries, even though caution is required when interpreting the coefficients' magnitudes given differences in the composition of national and world food baskets.

Global food inflation is an important source of domestic inflation in the MENA region. Pass-through effects are notably higher than the sample's average for West Bank and Gaza and Iraq, where world food price increases account for over $50 \%$ of food inflation, and Egypt, Djibouti, and the UAE, where they contribute $40 \%$ to food inflation. Algeria and Tunisia, on the other hand, appear least affected in the region. The price transmission process in most MENA economies is asymmetric, implying that both high global food price levels and price volatility matter for domestic food price inflation. Government interventions related to food price subsidies and controls, along with political insecurity in the region, may contribute to a sluggish response to downward movements in world food prices. Nonetheless, this article does not identify the underlying causes of the asymmetric food price transmission process. These are complex and can be an area for future research.

We employ aggregate price data, as our goal is to get a broad sense of countries' general vulnerability to global food price shocks. For a more in-depth understanding of pass-through effects, one would need to go beyond aggregate food price analysis, and estimate these effects by commodity. We, however, had no access to such disaggregate information. Thus, efforts should be made to collect more readily available domestic commodity price data in the MENA region. For a few MENA economies, only short time series were available, arguably resulting in lower precision of the pass-through estimates. In economies where the pass-through effects are large, in-depth country studies might be beneficial to disentangle more effectively 
the role and nature of different factors contributing to food inflation. Finally, world price movements can have important poverty and distributional effects within countries (Ivanic et al. 2011), but these issues are beyond the scope of this paper.

\section{Acknowledgements}

We thank Caroline Freund, Julian Lampietti, Joachim von Braun, two anonymous reviewers of this Journal, staff from the International Food Policy Research Institute, as well as participants of the Annual Meeting of the German Research Committee of Development Economics in Bonn and the $15^{\text {th }}$ Annual Conference on Global Economic Analysis in Geneva, for helpful comments and discussions. We are grateful to Cristina Savescu and Racquel Claveria for their research support. Data and code are available upon request from the authors. The views expressed in this paper are those of the authors and do not represent those of the World Bank or the African Development Bank or their member countries.

\section{References}

Adam, C. (2011). On the macroeconomic management of food price shocks in lowincome countries. Journal of African Economies, 20, i63-i99.

Albers, R. \& Peeters, M. (2011). Food and energy prices, government subsidies and fiscal balances in South Mediterranean countries. Economic Papers 437. Brussels: European Commission, Directorate General for Economic and Financial Affairs.

Anderson, K. (Ed.). (2010). The Political Economy of Agricultural Price Distortions. Cambridge and New York: Cambridge University Press.

Anderson, K. \& Tyers, R. (1992). Disarray in World Food Markets. Cambridge and New York: Cambridge University Press.

Barret, C.B. \& Bellemere, M.F. (2011). Why food price volatility doesn’t matter? Foreign Affairs, July 12.

Barrett, C.B. (2001). Measuring integration and efficiency in international agricultural markets. Review of Agricultural Economics, 23, 19-32.

Baffes, J. \& Gardner, B. (2003). The transmission of world commodity prices to domestic markets under policy reforms in developing countries. Policy Reform, 6, 159-180. 
Breisinger, C., Ecker, O., \& Al-Riffai, P. (2011). Economics of the Arab awakening: From revolution to transformation and food security. IFPRI Policy Brief 18. Washington DC: International Food Policy Institute.

Brümmer, B., Korn, O., Schlübler, K., Jaghdani, T., \& Saucedo, A. (2013). Volatility in the After Crisis Period - A Literature Review of Recent Empirical Research. Ulysses: Working Paper 1, Department of Agricultural Economics and Rural Development, University of Goettingen.

Crowley, J. (2010). Commodity Prices and Inflation in the Middle East, North Africa, and Central Asia. IMF Working Paper WP/10/135. Washington DC: International Monetary Fund.

Fackler, P.L. \& Goodwin, B.K. (2001). Spatial price analysis. In B.L. Gardner \& G.C. Rausser (Eds.). Handbook of Agricultural Economics (pp. 971-1024). Amsterdam: Elsevier.

FAO (2009). Iraq Food Prices Analysis. United Nations Food and Agricultural Organization: Inter-Agency Information and Analysis Unit. Processed manuscript.

Ferrucci, G., Jiménez-Rodriguez, R., \& Onorante, L. (2010). Food Price PassThrough in the Euro-Area: The Role of Asymmetries and Non-Linearities. Working Paper Series 1168. Frankfurt am Main: European Central Bank.

Greb, F., Jamora, N., Mengel, C., von Cramon-Taubadel, S., \& Wuerriehausen, N. (2012). Price Transmission from International to Domestic Markets. Global Food Discussion Papers 15. University of Goettingen.

Hazell, P.B., Jaramillo, M., \& Williamson, A. (1990). The relationship between world price instability and the prices farmers receive in developing countries. Journal of Agricultural Economics, 41, 227-241.

IMF (2011). World Economic Outlook. Washington DC: International Monetary Fund.

Ivanic, M., Martin, W., \& Hassan, Z. (2011). Estimating the short-run poverty impacts of the 2010-11 surge in food prices. World Bank Policy Research Working Paper 5633. Washington DC.

Lagi, M., Bertrand, K.Z., \& Bar-Yam, Y. (2011). The Food Crises and Political Instability in North Africa and the Middle East. Processed manuscript.

Meyer, J. \& Cramon-Taubadel, S. (2004). Asymmetric price transmission: A survey. Journal of Agricultural Economics, 55, 581-611. 
Morisset, J. (1998). Unfair trade? The increasing gap between world and domestic prices in commodity markets during the past 25 years. World Bank Economic Review, 12, 503-526.

Moghaddasi, R. (2009). Price transmission in agricultural markets: An Iranian experience. American-Eurasian Journal of Agriculture and Environmental Science, 6, 70-75.

Mundlak, Y. \& Larson, D. (1992). On the transmission of world agricultural prices. World Bank Economic Review, 6, 399-422.

Ortiz, I., Chai, J., \& Cummins, M. (2011). Escalating Food Prices: The Threat to Poor Households and Policies to Safeguard a Recovery for All. Social and Economic Policy Working Paper (February). New York: United Nations Children’s Fund.

Peltzman, S. (2000). Prices rise faster than they fall. Journal of Political Economy, 108, 466-502.

Quiroz, J. \& Soto, R. (1995). International Price Signals in Agricultural Prices: Do Governments Care? Washington, DC: ILADES/Georgetown University.

Sharma, R. (2003). The transmission of world price signals: concepts, issues, and some evidence from Asian cereal markets. In OECD (Ed.) Agricultural Trade and Poverty: Making Policy Analysis Count (pp. 119-139). Paris: Organisation for Economic Co-operation and Development.

Vavra, P. \& Goodwin, B.K. (2005). Analysis of Price Transmission along the Food Chain. OECD Food, Agriculture, and Fisheries Papers 3. Paris: Organisation of Economic Cooperation and Development.

Walsh, J.P. (2011). Reconsidering the Role of Food Prices in Inflation. IMF Working Paper WP/11/71. Washington DC: International Monetary Fund.

World Bank (2011a). Middle East and North Africa: Facing Challenges and Opportunities. Economic Developments and Prospects Report (May 2011). Washington DC.

World Bank (2011b). Middle East and North Africa: Investing for Growth and Jobs. Economic Developments and Prospects Report (September 2011). Washington DC.

World Bank (2012). The Grain Chain: Food Security and Managing Wheat Imports in Arab Countries. Washington DC. Processed manuscript. 
Zurayk, R. (2011). Food, Farming, and Freedom: Sowing the Arab Spring. Charlottesville Virginia: Just World Books. 


\section{Notes}

${ }^{1}$ We use interchangeably the terms MENA and Arab world. MENA includes most members of the Arab League and Iran. We refer to three main MENA country subgroups: the oil importing economies (Egypt, Tunisia, Morocco, Jordan, Lebanon, Djibouti, and West Bank and Gaza); the developing oil exporting economies (Algeria, Iran, Iraq, Syria, and Yemen); and the Gulf Cooperation Council (GCC) economies (UAE, Saudi Arabia, Qatar, Oman, Bahrain, and Kuwait). Developing MENA includes the oil importing and developing oil exporting countries in the region.

${ }^{2}$ Food price subsidies have been part of the social contract in the region for decades. In addition to subsidies, governments employ other policies to manage and regulate food consumption, production, and trade. These include production subsidies, import protection cuts, and build-up of food reserves (Ortiz et al. 2011). The Agricultural Distortions Database, used by Anderson (2010), provides information on policy distortions that drive a wedge between domestic and international prices for many countries. Information on MENA countries is largely absent from it.

${ }^{3}$ Brümmer et al. (2013) argue that the perceived trend towards higher price volatility can only be robustly confirmed for cereals.

${ }^{4}$ International food prices, measured by the World Bank food price index, increased by more than $70 \%$ from 2006 to 2011. International prices of food continued to decline thereafter, but remain close to alltime highs.

${ }^{5}$ Barret and Bellemere (2011) argue that in the popular policy debate there is confusion between rising food price levels and price volatility as both terms are often used synonymously. They argue that the core problem for most developing countries is the high food global price level, and not so much price volatility.

${ }^{6}$ Despite low domestic food price inflation, high unemployment, poor quality services, and policies favouring privileged businesses fuelled the popular discontent in Tunisia (World Bank 2013).

${ }^{7}$ Most MENA countries spent several percentage points of their GDP on food subsidies. In 2009, food subsidies ranged from $0.8 \%$ of GDP in Jordan to 3.5\% of GDP in Iraq (World Bank 2011a). Albers and Peeters (2011) provide additional estimates.

${ }^{8}$ Food consumption shares are close to $60 \%$ in low-income MENA (for example Yemen and Djibouti), between 35\% and 45\% in middle-income MENA (Morocco, Algeria, Lebanon, Jordan, Syria, Egypt, Tunisia, Iraq), and below 25\% in the GCC economies.

${ }^{9}$ Theoretically, the pass-through coefficients can range from zero, in the case of no transmission, to one, in the case of full transmission.

${ }^{10}$ The average pass-through effect in the literature is estimated to be around 0.3 .

${ }^{11}$ These assumptions are motived by the fact that transport costs are sticky in most MENA countries given the widespread use of energy subsidies. Import tariffs, unlike subsidies, are not designed to change frequently in order to absorb fluctuations in prices as conditions in domestic and world commodity markets change. Changes to tariffs typically have to be ratified by parliaments and comply with conditions negotiated as part of international treaties. Finally, most MENA countries maintain fixed nominal exchange rates or exchange rates that vary within tightly managed bands.

${ }^{12}$ In MENA's oil importing countries, for example, fiscal deficits grew from an average of about $4 \%$ of GDP in 2008 to $7.5 \%$ of GDP in 2011. While government debt declined, it remained above $70 \%$ of GDP since 2008.

${ }^{13}$ The food CPI increased by 20\% in Jordan, 44\% in Egypt, 21\% in Syria, and 8\% in Morocco between 2007 and 2009.

${ }^{14}$ According to World Bank data, during the period 2007-09, food subsidies declined as a share of GDP from $1.8 \%$ to $0.8 \%$ in Jordan, and from $2.1 \%$ to $1.4 \%$ in Syria. Food subsidies remained at $0.7 \%$ in Morocco, and increased from 1.3\% to 2.0\% in Egypt.

${ }^{15}$ Note that the analysis does not change if we assume that the country is a price taker in international food markets and faces a perfectly elastic import supply curve.

${ }^{16}$ Import supply MS will shift either because of shifts in global supply or shifts in global demand.

17 Albers et al. (2011) provide evidence of asymmetry in international food price transmission for a number of Mediterranean MENA countries.

${ }^{18}$ Missing values were linearly interpolated with those of the same month in the previous and following years.

${ }^{19}$ We assume that import prices are the prices prevailing in major international markets for each commodity, expressed in US\$, and that in the very short-run demand and supply do not respond to changes in prices. 
${ }^{20}$ It appears unlikely that differences in the composition of international and domestic food price indices have sufficient power to explain the lack of significance of the co-integration test for the period of investigation. The domestic and international food price indexes are similar in principle due to the large share of cereals, cooking oils, and sugar in their composition. The largest components of the domestic price indexes in MENA countries are the largest components of the World Bank food price index. In addition, using the same domestic and international food price indexes, we find short-run but not long-run correlations.

${ }^{21}$ Impulse response functions allow us to trace out the time path of the effect of structural food price shocks from the autoregressive model. Accumulated impulse response functions compute the cumulative sum of the shock over time. We find that the estimates are robust to Cholesky ordering effects.

${ }^{22}$ Details are available upon request. Impulse dummies and time trends are only included if significant at the 1 percent level. The individual country models include between zero and up to three dummies to correct for extreme outlier effects and underlying trends. The price transmission coefficients are generally insensitive to the inclusion of the variables, although the standard errors are affected.

${ }^{23}$ The average pass-through effect for the MENA sample is estimated to equal 0.3 .

${ }^{24}$ To allow a consistent comparison we maintain the asymmetric model specification for all countries.

${ }^{25}$ The FAO (2009) finds that in Iraq changes in the wholesale price are not met with proportional changes in the retail price. Moghaddasi (2009) reports similar findings for Iran.

${ }^{26}$ Food inflation has accelerated in Iran since December 2010 when the government removed subsidies on energy, water, bread, and other basic products.

${ }^{27}$ In Oman the pass-through effects appear after just 3 months.

${ }^{28}$ Individual country results are presented in the online Appendix, Table A5. 
Appendix Table A1. Annual Food Inflation Rates by Country in MENA (in \%)

\begin{tabular}{lrrrrrrrrrrrrrrr}
\hline Country & 2000 & 2001 & 2002 & 2003 & 2004 & 2005 & 2006 & 2007 & 2008 & 2009 & 2010 & 2011 Mean \\
\hline Bahrain & -1.3 & -1.4 & -0.9 & -1.5 & 2.2 & 3.0 & 2.0 & 7.4 & 7.2 & 9.1 & 4.9 & 2.0 & 2.7 \\
Kuwait & 1.2 & -0.4 & 1.3 & 5.3 & 3.2 & 8.5 & 3.9 & 4.7 & 10.7 & 3.2 & 8.3 & 9.7 & 4.9 \\
Oman & & & & -0.1 & 1.1 & 4.0 & 5.8 & 10.7 & 20.1 & 0.8 & 2.1 & 4.6 & 5.3 \\
Qatar & & & 1.3 & -0.3 & 3.6 & 3.2 & 6.9 & 7.3 & 12.4 & 6.9 & 2.2 & 4.2 & 4.7 \\
Saudi Arabia & -0.9 & 0.6 & -0.6 & -3.0 & 2.5 & 3.0 & 5.3 & 7.0 & 13.2 & 2.0 & 6.2 & 5.2 & 3.3 \\
United Arab Emirates & & & & & & & & & 10.8 & 0.9 & 4.4 & 5.9 & 5.4 \\
Algeria & -2.1 & 4.6 & 1.9 & 4.6 & 5.0 & 0.2 & 2.4 & 6.3 & 5.5 & 11.2 & 5.2 & 5.9 & 4.2 \\
Iran, Islamic Rep. & -0.7 & 0.3 & 0.2 & 1.8 & 5.4 & 5.2 & 7.5 & 10.0 & 26.6 & 12.3 & 12.5 & 26.2 & 8.6 \\
Iraq & & & & & & & 29.9 & 14.6 & 9.6 & 8.0 & 2.2 & 3.1 & 10.9 \\
Syrian Arab Rep. & -1.0 & -0.3 & -0.5 & 7.8 & 5.2 & 8.6 & 12.9 & 9.0 & 19.4 & 0.4 & 4.7 & 7.8 & 6.0 \\
Yemen, Rep. & & & & & 19.0 & 19.5 & 33.5 & 19.4 & 2.7 & 4.7 & 12.8 & 15.0 & 15.5 \\
Djibouti & & & & & & & 9.7 & 9.9 & 22.8 & 6.7 & 3.8 & 8.2 & 10.0 \\
Jordan & -0.7 & 0.3 & 0.2 & 1.8 & 5.4 & 5.2 & 7.5 & 9.4 & 17.6 & 1.1 & 5.0 & 4.2 & 4.6 \\
Lebanon & & & & & & & & & 8.5 & 4.0 & 3.1 & 6.5 & 5.5 \\
Egypt, Arab Rep. & 2.5 & 1.1 & 4.5 & 11.2 & 22.0 & 5.1 & 10.1 & 13.1 & 22.1 & 16.1 & 19.9 & 15.8 & 11.7 \\
Morocco & 1.5 & -1.0 & 4.3 & 1.4 & 1.6 & 0.3 & 3.9 & 3.3 & 6.2 & 1.3 & 5.0 & 1.4 & 2.4 \\
Tunisia & 4.5 & 1.7 & 4.3 & 3.4 & 5.1 & 0.1 & 5.4 & 2.8 & 6.0 & 4.3 & 6.5 & 3.7 & 4.0 \\
West Bank and Gaza & 0.9 & 4.3 & 18.1 & 28.0 & 32.5 & 38.5 & 46.4 & 50.3 & 52.2 & 64.7 & 68.0 & 75.6 & 38.0 \\
World Food Prices & -3.1 & 2.2 & 6.9 & 8.6 & 13.2 & -1.7 & 10.8 & 25.4 & 38.8 & -13.7 & 9.0 & 25.6 & 9.3 \\
\hline
\end{tabular}




\begin{tabular}{|c|c|c|c|c|c|c|}
\hline Country & $p$ & $\Delta p$ & $e$ & $\Delta e$ & Time Period & Obs. \\
\hline Bahrain & 0.95 & -16.70 & -1.18 & -8.66 & 2000:12-2011:06 & 127 \\
\hline Kuwait & 2.32 & -11.90 & -1.10 & -8.61 & 2000:12-2011:06 & 127 \\
\hline Oman & -0.02 & -5.56 & -1.77 & -5.22 & 2003:01-2011:06 & 102 \\
\hline Qatar & 1.40 & -16.98 & -1.18 & -8.69 & 2002:01-2011:06 & 114 \\
\hline Saudi Arabia & 1.83 & -5.75 & -1.18 & -8.66 & 2000:12-2011:08 & 129 \\
\hline UAE & -1.77 & -3.96 & -1.18 & -8.66 & 2008:01-2011:10 & 46 \\
\hline Algeria & -0.05 & -10.40 & -1.11 & -9.49 & 2000:12-2011:08 & 129 \\
\hline Iran & -1.82 & -7.63 & -0.96 & -11.01 & 2000:12-2011:04 & 125 \\
\hline Iraq & -1.83 & -7.63 & -1.57 & -10.83 & 2006:01-2011:09 & 69 \\
\hline Syria & -1.23 & -4.29 & -1.60 & -9.16 & 2006:12-2011:09 & 58 \\
\hline Yemen & -0.96 & -7.63 & -1.81 & -9.80 & 2004:01-2011:04 & 88 \\
\hline Djibouti & -1.81 & -5.76 & -0.80 & -9.98 & 2005:10-2011:09 & 72 \\
\hline Egypt & 2.63 & -8.27 & -0.99 & -8.85 & 2000:12-2011:08 & 129 \\
\hline Jordan & 0.54 & -9.82 & -1.18 & -8.66 & 2000:12-2011:10 & 131 \\
\hline Lebanon & -2.38 & -4.64 & -1.21 & -8.60 & 2008:01-2011:10 & 46 \\
\hline Morocco & 1.26 & -10.40 & -1.02 & -9.47 & 2000:12-2011:10 & 131 \\
\hline Tunisia & 0.71 & -6.73 & -0.81 & -9.98 & 2000:12-2011:03 & 124 \\
\hline WBG & 1.46 & -11.19 & -1.36 & -6.41 & 2000:12-2011:06 & 127 \\
\hline$w f p$ & -0.43 & -6.27 & $\ldots$ & $\ldots$ & $2000: 12-2011: 10$ & 131 \\
\hline
\end{tabular}

Note: Bold numbers indicate MacKinnon one-sided probability levels at 5 percent or better. Test equations assume constant and trend with 4 lags (Lebanon and UAE equations include 2 lags). Results are robust to specifications with 8 and 12 lags, although the power of the ADF test statistics is reduced. 
Appendix Table A3. Johansen Cointegration Test (Maximum Eigenvalue Rank)

\begin{tabular}{|c|c|c|c|c|c|c|}
\hline \multirow{3}{*}{ Country } & \multicolumn{3}{|c|}{$\begin{array}{l}\text { No co-integrating equation with } \\
\qquad w f p\end{array}$} & \multicolumn{3}{|c|}{$\begin{array}{l}\text { At least one co-integrating equation with } \\
\qquad w f p\end{array}$} \\
\hline & \multicolumn{3}{|c|}{ Eigenvalue } & \multicolumn{3}{|c|}{ Max-Eigenvalue } \\
\hline & Eigenvalue & Statistic & Probability & Eigenvalue & Statistic & Probability \\
\hline Bahrain & 0.10 & 14.58 & 0.22 & 0.07 & 10.03 & 0.13 \\
\hline Kuwait & 0.11 & 16.03 & 0.14 & 0.06 & 8.65 & 0.20 \\
\hline Oman & 0.07 & 6.32 & 0.31 & 0.02 & 1.54 & 0.25 \\
\hline Qatar & 0.11 & 12.14 & 0.40 & 0.05 & 5.67 & 0.50 \\
\hline Saudi Arabia & 0.06 & 7.80 & 0.84 & 0.05 & 6.29 & 0.42 \\
\hline UAE & 0.24 & 9.65 & 0.66 & 0.15 & 5.66 & 0.50 \\
\hline Algeria & 0.09 & 12.54 & 0.37 & 0.06 & 8.44 & 0.22 \\
\hline Iran & 0.05 & 6.19 & 0.33 & 0.01 & 0.89 & 0.40 \\
\hline Iraq & 0.24 & 16.22 & 0.14 & 0.06 & 3.78 & 0.77 \\
\hline Syria & 0.29 & 15.80 & 0.15 & 0.11 & 5.60 & 0.51 \\
\hline Yemen & 0.13 & 11.23 & 0.49 & 0.07 & 5.97 & 0.46 \\
\hline Djibouti & 0.21 & 11.44 & 0.47 & 0.11 & 5.85 & 0.48 \\
\hline Egypt & 0.10 & 14.87 & 0.20 & 0.07 & 9.88 & 0.13 \\
\hline Jordan & 0.11 & 17.32 & 0.10 & 0.08 & 11.63 & 0.07 \\
\hline Lebanon & 0.21 & 7.97 & 0.82 & 0.13 & 4.54 & 0.66 \\
\hline Morocco & 0.02 & 2.84 & 0.81 & 0.01 & 1.52 & 0.26 \\
\hline Tunisia & 0.09 & 13.92 & 0.26 & 0.06 & 9.44 & 0.15 \\
\hline WBG & 0.11 & 15.84 & 0.15 & 0.08 & 12.19 & 0.06 \\
\hline
\end{tabular}

Note: Tests include a constant and trend line in the co-integrating equation with 4 lags (two lags for Lebanon and UAE). Results are to specifications with 8 and 12 lags for all countries except Saudi Arabia. 


\section{Appendix Table A4. Summary of Food Price Regression Results}

\begin{tabular}{|c|c|c|c|c|c|c|c|c|c|c|}
\hline \multirow[t]{2}{*}{ Country } & \multirow[t]{2}{*}{ Constant } & \multirow[t]{2}{*}{$\mathrm{p}_{\mathrm{i}}$} & \multicolumn{2}{|c|}{$\begin{array}{c}\text { Cumulative food price } \\
\text { pass-through }\end{array}$} & \multicolumn{2}{|c|}{$\begin{array}{l}\text { Cumulative exchange } \\
\text { rate pass-trough }\end{array}$} & \multirow{2}{*}{$\begin{array}{l}\text { Time } \\
\text { trend }\end{array}$} & \multirow[t]{2}{*}{ Lags } & \multirow[t]{2}{*}{ Adj. $R^{2}$} & \multirow[t]{2}{*}{ Obs. } \\
\hline & & & $\delta^{+}$ & $\delta$ & $\gamma^{+}$ & $\gamma^{-}$ & & & & \\
\hline Bahrain & $\begin{array}{l}-4.515 \\
-(2.30)\end{array}$ & $\begin{array}{l}\mathbf{0 . 4 4 1} \\
(0.08)\end{array}$ & $\begin{array}{l}\mathbf{0 . 3 4 9} \\
(0.11)\end{array}$ & $\begin{array}{l}0.051 \\
(0.03)\end{array}$ & $\begin{array}{l}0.115 \\
(0.08)\end{array}$ & $\begin{array}{l}0.044 \\
(0.05)\end{array}$ & $\begin{array}{l}0.075 \\
(0.01)\end{array}$ & 12 & 0.801 & 127 \\
\hline Kuwait & $\begin{array}{l}-0.082 \\
-(0.47)\end{array}$ & $\begin{array}{l}\mathbf{0 . 6 0 5} \\
(0.10)\end{array}$ & $\begin{array}{l}\mathbf{0 . 2 7 9} \\
(0.13)\end{array}$ & $\begin{array}{l}0.020 \\
(0.03)\end{array}$ & $\begin{array}{l}0.064 \\
(0.08)\end{array}$ & $\begin{array}{l}0.033 \\
(0.06)\end{array}$ & $\begin{array}{l}0.018 \\
(0.01)\end{array}$ & 12 & 0.765 & 127 \\
\hline Oman & $\begin{array}{l}-7.733 \\
-(4.28)\end{array}$ & $\begin{array}{l}\mathbf{0 . 3 4 9} \\
(0.13)\end{array}$ & $\begin{array}{l}0.213 \\
(0.13)\end{array}$ & $\begin{array}{l}0.075 \\
(0.07)\end{array}$ & $\begin{array}{l}0.104 \\
(0.13)\end{array}$ & $\begin{array}{l}0.258 \\
(0.15)\end{array}$ & $\begin{array}{l}0.092 \\
(0.05)\end{array}$ & 12 & 0.897 & 102 \\
\hline Qatar & $\begin{array}{l}2.806 \\
(1.49)\end{array}$ & $\begin{array}{l}0.089 \\
(0.08)\end{array}$ & $\begin{array}{l}0.355 \\
(0.16)\end{array}$ & $\begin{array}{l}0.220 \\
(0.10)\end{array}$ & $\begin{array}{l}0.117 \\
(0.10)\end{array}$ & $\begin{array}{c}0.218 \\
(0.11)\end{array}$ & $\cdots$ & 12 & 0.748 & 114 \\
\hline Saudi Arabia & $\begin{array}{l}-0.154 \\
-(0.12)\end{array}$ & $\begin{array}{l}0.433 \\
(0.41)\end{array}$ & $\begin{array}{l}0.266 \\
(0.23)\end{array}$ & $\begin{array}{l}0.023 \\
(0.02)\end{array}$ & $\begin{array}{l}0.026 \\
(0.10)\end{array}$ & $\begin{array}{c}0.251 \\
(0.11)\end{array}$ & $\cdots$ & 12 & 0.881 & 129 \\
\hline UAE & $\begin{array}{l}1.956 \\
(0.40)\end{array}$ & $\begin{array}{l}0.116 \\
(0.12)\end{array}$ & $\begin{array}{l}0.413 \\
(0.20)\end{array}$ & $\begin{array}{l}0.315 \\
(0.16)\end{array}$ & $\begin{array}{l}0.009 \\
(0.07)\end{array}$ & $\begin{array}{c}0.147 \\
(0.10)\end{array}$ & $\cdots$ & 2 & 0.855 & 46 \\
\hline Algeria & $\begin{array}{l}0.245 \\
(0.56)\end{array}$ & $\begin{array}{l}\mathbf{0 . 4 4 4} \\
(0.10)\end{array}$ & $\begin{array}{l}0.059 \\
(0.07)\end{array}$ & $\begin{array}{l}0.048 \\
(0.04)\end{array}$ & $\begin{array}{l}0.248 \\
(0.10)\end{array}$ & $\begin{array}{l}0.201 \\
(0.09)\end{array}$ & $\begin{array}{r}0.023 \\
(0.01)\end{array}$ & 12 & 0.783 & 129 \\
\hline Iran & $\begin{array}{l}-4.560 \\
-(1.32)\end{array}$ & $\begin{array}{l}0.579 \\
(0.11)\end{array}$ & $\begin{array}{l}0.282 \\
(0.12)\end{array}$ & $\begin{array}{l}0.052 \\
(0.04)\end{array}$ & $\begin{array}{l}0.040 \\
(0.07)\end{array}$ & $\begin{array}{l}0.047 \\
(0.04)\end{array}$ & $\begin{array}{l}0.089 \\
(0.02)\end{array}$ & 12 & 0.849 & 125 \\
\hline Iraq & $\begin{array}{l}-7.512 \\
-(2.89)\end{array}$ & $\begin{array}{l}0.205 \\
(0.12)\end{array}$ & $\begin{array}{l}0.497 \\
(0.16)\end{array}$ & $\begin{array}{l}0.055 \\
(0.10)\end{array}$ & $\begin{array}{l}0.162 \\
(0.13)\end{array}$ & $\begin{array}{l}0.080 \\
(0.05)\end{array}$ & $\cdots$ & 6 & 0.602 & 69 \\
\hline Syria & $\begin{array}{l}-1.670 \\
-(0.52)\end{array}$ & $\begin{array}{l}0.556 \\
(0.19)\end{array}$ & $\begin{array}{l}0.261 \\
(0.11)\end{array}$ & $\begin{array}{l}0.100 \\
(0.07)\end{array}$ & $\begin{array}{l}0.058 \\
(0.14)\end{array}$ & $\begin{array}{l}0.025 \\
(0.06)\end{array}$ & $\begin{array}{r}1.213 \\
(0.38)\end{array}$ & 5 & 0.895 & 58 \\
\hline Yemen & $\begin{array}{l}-5.663 \\
-(4.98)\end{array}$ & $\begin{array}{l}0.229 \\
(0.13)\end{array}$ & $\begin{array}{l}0.311 \\
(0.17)\end{array}$ & $\begin{array}{l}0.234 \\
(0.19)\end{array}$ & $\begin{array}{l}0.189 \\
(0.11)\end{array}$ & $\begin{array}{l}0.037 \\
(0.06)\end{array}$ & $\begin{array}{l}\mathbf{0 . 5 6 8} \\
(0.05)\end{array}$ & 10 & 0.821 & 88 \\
\hline Djibouti & $\begin{array}{l}0.451 \\
(1.04)\end{array}$ & $\begin{array}{l}0.204 \\
(0.15)\end{array}$ & $\begin{array}{l}\mathbf{0 . 4 6 4} \\
(0.18)\end{array}$ & $\begin{array}{l}0.129 \\
(0.11)\end{array}$ & $\begin{array}{l}0.148 \\
(0.11)\end{array}$ & $\begin{array}{r}0.055 \\
(0.13)\end{array}$ & $\ldots$ & 4 & 0.859 & 72 \\
\hline Egypt & $\begin{array}{r}-1.760 \\
-(0.48)\end{array}$ & $\begin{array}{l}\mathbf{0 . 3 6 6} \\
(0.10)\end{array}$ & $\begin{array}{l}\mathbf{0 . 4 4 1} \\
(0.14)\end{array}$ & $\begin{array}{l}0.034 \\
(0.03)\end{array}$ & $\begin{array}{l}0.110 \\
(0.09)\end{array}$ & $\begin{array}{l}0.049 \\
(0.06)\end{array}$ & $\begin{array}{l}\mathbf{0 . 0 5 0} \\
(0.01)\end{array}$ & 12 & 0.876 & 129 \\
\hline Jordan & $\begin{array}{l}-1.049 \\
-(0.61)\end{array}$ & $\begin{array}{l}0.304 \\
(0.10)\end{array}$ & $\begin{array}{l}0.392 \\
(0.12)\end{array}$ & $\begin{array}{l}0.130 \\
(0.07)\end{array}$ & $\begin{array}{l}0.110 \\
(0.10)\end{array}$ & $\begin{array}{c}0.064 \\
(0.06)\end{array}$ & $\begin{array}{l}0.025 \\
(0.01)\end{array}$ & 12 & 0.802 & 131 \\
\hline Lebanon & $\begin{array}{l}7.025 \\
(3.75)\end{array}$ & $\begin{array}{l}0.286 \\
(0.19)\end{array}$ & $\begin{array}{l}0.180 \\
(0.21)\end{array}$ & $\begin{array}{l}0.132 \\
(0.09)\end{array}$ & $\begin{array}{l}0.057 \\
(0.09)\end{array}$ & $\begin{array}{c}0.344 \\
(0.12)\end{array}$ & $\begin{array}{l}-0.509 \\
-(0.27)\end{array}$ & 2 & 0.704 & 46 \\
\hline Morocco & $\begin{array}{l}-0.722 \\
-(0.47)\end{array}$ & $\begin{array}{l}0.392 \\
(0.09)\end{array}$ & $\begin{array}{l}0.394 \\
(0.12)\end{array}$ & $\begin{array}{l}0.052 \\
(0.04)\end{array}$ & $\begin{array}{l}0.144 \\
(0.07)\end{array}$ & $\begin{array}{l}0.018 \\
(0.03)\end{array}$ & $\begin{array}{l}0.025 \\
(0.01)\end{array}$ & 12 & 0.770 & 131 \\
\hline Tunisia & $\begin{array}{l}\mathbf{0 . 5 4 9} \\
(0.24)\end{array}$ & $\begin{array}{l}\mathbf{0 . 5 6 5} \\
(0.13)\end{array}$ & $\begin{array}{l}0.058 \\
(0.09)\end{array}$ & $\begin{array}{l}0.005 \\
(0.03)\end{array}$ & $\begin{array}{l}0.290 \\
(0.14)\end{array}$ & $\begin{array}{l}0.082 \\
(0.09)\end{array}$ & $\begin{array}{c}0.011 \\
(0.00)\end{array}$ & 12 & 0.848 & 124 \\
\hline WBG & $\begin{array}{l}-0.346 \\
-(0.36)\end{array}$ & $\begin{array}{l}0.281 \\
(0.08)\end{array}$ & $\begin{array}{l}\mathbf{0 . 6 5 8} \\
(0.13)\end{array}$ & $\begin{array}{l}0.017 \\
(0.04)\end{array}$ & $\begin{array}{l}0.014 \\
(0.06)\end{array}$ & $\begin{array}{l}0.030 \\
(0.07)\end{array}$ & $\cdots$ & 12 & 0.833 & 127 \\
\hline
\end{tabular}

Note: Bootstrapped standard errors are in parentheses. Bold numbers indicate significance levels at 5 percent or better. With the exception of the UAE, Djibouti and Lebanon, the equations include impulse dummies to correct for outliers. Lag length selection is according to AIC and Wald lag exclusion tests. 
Appendix Table A5. Variance Decomposition of Changes in Domestic Food Prices (in \%)

\begin{tabular}{|c|c|c|c|c|c|c|c|c|c|c|c|c|c|}
\hline & S.E. & $\Delta w f p^{+}$ & $\Delta w f p^{-}$ & $\Delta e^{+}$ & $\Delta e^{-}$ & $\Delta p_{i}$ & & S.E. & $\Delta w f p^{+}$ & $\Delta w f p^{-}$ & $\Delta e^{+}$ & $\Delta e^{-}$ & $\Delta p_{i}$ \\
\hline Bahrain & & & & & & & Syria & & & & & & \\
\hline 2 months & 1.38 & 0.0 & 0.0 & 2.4 & 0.0 & 97.5 & 2 months & 2.42 & 0.9 & 0.0 & 7.8 & 0.8 & 90.5 \\
\hline 6 months & 1.87 & 6.3 & 7.1 & 10.6 & 6.6 & 69.4 & 6 months & 6.14 & 19.2 & 6.6 & 5.6 & 2.4 & 66.2 \\
\hline 12 months & 2.60 & 33.8 & 5.4 & 11.2 & 4.9 & 44.6 & 12 months & 10.13 & 25.7 & 9.7 & 5.7 & 2.6 & 56.4 \\
\hline Kuwait & & & & & & & Yemen & & & & & & \\
\hline 2 months & 1.84 & 0.1 & 0.2 & 0.1 & 0.7 & 98.9 & 2 months & 5.99 & 26.8 & 0.1 & 0.0 & 0.2 & 72.9 \\
\hline 6 months & 2.54 & 18.8 & 1.5 & 0.4 & 3.4 & 75.9 & 6 months & 12.42 & 34.7 & 22.1 & 16.4 & 3.0 & 23.8 \\
\hline 12 months & 3.03 & 26.1 & 2.3 & 6.6 & 3.4 & 61.6 & 12 months & 15.05 & 30.7 & 23.6 & 16.9 & 4.8 & 24.1 \\
\hline Oman & & & & & & & Djibouti & & & & & & \\
\hline 2 months & 0.72 & 14.1 & 0.9 & 0.8 & 23.6 & 60.6 & 2 months & 3.04 & 11.3 & 4.8 & 4.7 & 1.7 & 77.5 \\
\hline 6 months & 1.69 & 25.5 & 5.9 & 9.5 & 6.3 & 52.8 & 6 months & 6.79 & 63.9 & 4.3 & 4.4 & 1.6 & 25.7 \\
\hline 12 months & 3.02 & 20.6 & 5.9 & 12.8 & 32.7 & 28.1 & 12 months & 11.91 & 42.3 & 13.5 & 16.5 & 7.4 & 20.3 \\
\hline Qatar & & & & & & & Egypt & & & & & & \\
\hline 2 months & 2.28 & 21.6 & 8.0 & 4.3 & 2.1 & 63.9 & 2 months & 1.83 & 0.3 & 2.9 & 0.8 & 2.0 & 94.1 \\
\hline 6 months & 4.99 & 32.4 & 16.5 & 9.6 & 24.7 & 16.8 & 6 months & 3.48 & 37.4 & 3.5 & 3.6 & 5.4 & 50.2 \\
\hline 12 months & 7.89 & 38.7 & 21.1 & 10.9 & 20.7 & 8.6 & 12 months & 5.38 & 36.3 & 3.8 & 20.8 & 3.9 & 35.2 \\
\hline Saudi Arabia & & & & & & & Jordan & & & & & & \\
\hline 2 months & 0.66 & 0.0 & 0.0 & 0.0 & 0.0 & 100.0 & 2 months & 2.54 & 0.2 & 0.3 & 0.3 & 0.2 & 99.0 \\
\hline 6 months & 2.01 & 21.9 & 2.9 & 0.6 & 11.4 & 63.2 & 6 months & 4.07 & 36.2 & 5.2 & 2.5 & 9.1 & 47.0 \\
\hline 12 months & 3.14 & 24.6 & 2.3 & 2.8 & 27.7 & 42.7 & 12 months & 5.17 & 38.5 & 13.7 & 11.2 & 6.3 & 30.3 \\
\hline UAE & & & & & & & Lebanon & & & & & & \\
\hline 2 months & 1.00 & 0.7 & 4.3 & 0.8 & 5.9 & 88.4 & 2 months & 2.02 & 1.1 & 2.0 & 2.4 & 6.6 & 87.9 \\
\hline 6 months & 2.52 & 39.0 & 30.5 & 0.7 & 14.7 & 15.1 & 6 months & 3.62 & 15.0 & 13.8 & 5.7 & 35.5 & 30.1 \\
\hline 12 months & 2.92 & 41.3 & 31.5 & 0.9 & 14.7 & 11.6 & 12 months & 3.80 & 18.2 & 13.2 & 5.8 & 34.4 & 28.3 \\
\hline Algeria & & & & & & & Morocco & & & & & & \\
\hline 2 months & 2.63 & 0.3 & 0.0 & 0.0 & 1.2 & 98.5 & 2 months & 1.37 & 0.3 & 0.2 & 0.6 & 0.3 & 98.6 \\
\hline 6 months & 3.19 & 7.0 & 6.4 & 9.2 & 2.7 & 74.7 & 6 months & 1.68 & 4.3 & 8.4 & 7.7 & 1.0 & 78.7 \\
\hline 12 months & 4.40 & 5.3 & 4.9 & 23.1 & 23.9 & 42.8 & 12 months & 2.58 & 40.4 & 5.0 & 13.8 & 2.7 & 38.2 \\
\hline Iran & & & & & & & Tunisia & & & & & & \\
\hline 2 months & 2.79 & 1.1 & 0.1 & 0.5 & 0.3 & 98.0 & 2 months & 0.93 & 1.0 & 0.1 & 0.1 & 0.1 & 98.8 \\
\hline 6 months & 3.78 & 16.8 & 0.5 & 4.5 & 3.6 & 74.7 & 6 months & 1.56 & 7.6 & 0.4 & 13.9 & 1.2 & 77.0 \\
\hline 12 months & 4.90 & 25.5 & 6.5 & 3.6 & 4.2 & 60.2 & 12 months & 1.89 & 5.5 & 0.6 & 30.3 & 8.8 & 54.8 \\
\hline Iraq & & & & & & & WBG & & & & & & \\
\hline 2 months & 4.41 & 6.1 & 5.6 & 12.6 & 2.1 & 73.6 & 2 months & 2.16 & 12.9 & 0.1 & 4.8 & 0.0 & 82.1 \\
\hline 6 months & 6.27 & 30.2 & 7.0 & 12.9 & 11.0 & 38.9 & 6 months & 4.79 & 52.3 & 1.4 & 2.0 & 2.2 & 42.2 \\
\hline 12 months & 9.48 & 49.4 & 5.7 & 16.4 & 7.9 & 20.6 & 12 months & 7.09 & 67.4 & 2.0 & 1.4 & 3.0 & 26.2 \\
\hline
\end{tabular}

